\title{
SGD
} Sosyal Güvenlik Dergisi
Journal of Social Security

P-ISSN: $2146-4839$

E-ISSN: $2148-483 \mathrm{X}$

\section{Türkiye'de İş-Aile Yaşamına Yönelik Düzenlemelerin Uluslararası Normlar ve Refah Rejimleri Çerçevesinde Değerlendirilmesi}

\section{Evaluation of Work-Family Life Regulations in Turkey within the Framework of International Norms and Welfare Regimes}

\section{Sera YILDIRIM DALYAN}

İstanbul Üniversitesi, İktisat Fakültesi, Çalışma Ekonomisi ve Endüstri İlişkileri Bölümü

\author{
Aralik 2020, Cilt 10, Say1 2, Sayfa 371-392 \\ December 2020, Volume 10, Issue 2, Page \\ 371-392 \\ P-ISSN: 2146-4839 \\ E-ISSN: 2148-483X
}

$2020-2$

e-posta: sgd@sgk.gov.tr

Yazılar yayınlanmak üzere kabul edildiği takdirde, SGD elektronik ortamda tam metin olarak yayımlamak da dahil olmak üzere, tüm yayın haklarına sahip olacaktır. Yayınlanan yazılardaki görüşlerin sorumluluğu yazarına aittir. Yazı ve tablolardan kaynak gösterilerek alıntı yapılabilir.

If the manuscripts are accepted to be published, the SGD has the possession of right of publicationand the copyright of the manuscripts, included publishing the whole text in the digital area. Articles published in the journal represent solely the views of the authors.

Some parts of the articles and the tables can be citeded by showing the source. 


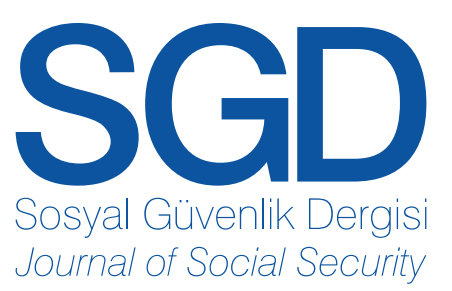

Cilt: 10 - Say1: 2 - Y11: 2020

Volume: 10 - Issue: 2 - Year: 2020

P-ISSN: 2146-4839

E-ISSN: 2148-483X

Sahibi / Owner of the Journal

Sosyal Güvenlik Kurumu Adına / On behalf of the Social Security Institution

İsmail YILMAZ

(Kurum Başkanı / President of the Institution)

Sorumlu Yazı İşleri Müdürü / Responsible Publication Manager

Uğur KORKMAZ

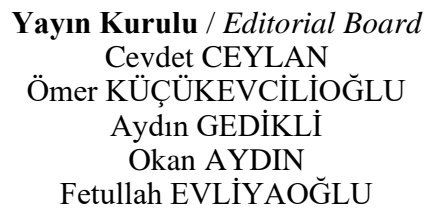

Editörler / Editors

Doç. Dr. Erdem CAM

Selda DEMİR

Redaksiyon / Redaction

Nihan ERTÜRK

Yayın Türü: Uluslararası Süreli Yayın / Type of Publication: International Periodical

Yayın Aralığı: 6 aylık / Frequency of Publication: Twice a Year

Dili: Türkçe ve İngilizce / Language: Turkish and English

Basım Tarihi / Press Date: 20.12.2020

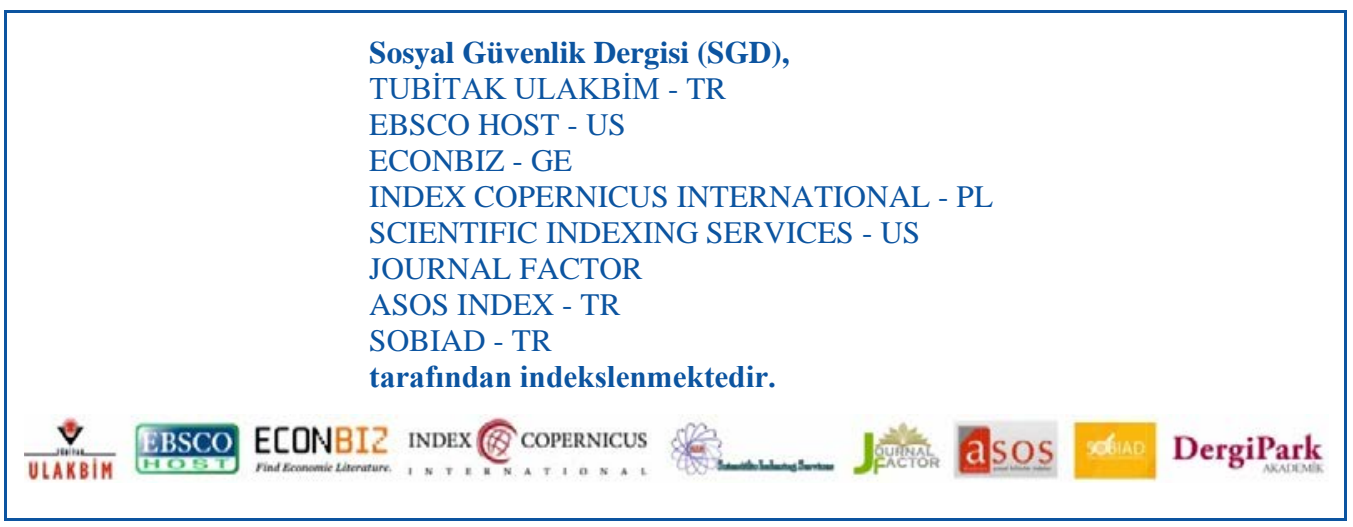

CTüm hakları saklıdır. Sosyal Güvenlik Dergisi’nde yer alan bilimsel çalışmaların bir kısmı ya da tamamı telif hakları saklı kalmak üzere eğitim, araştırma ve bilimsel amaçlarla çoğaltılabilir. Dergide yayımlanan makalelerdeki fikir ve görüşler Sosyal Güvenlik Kurumunun kurumsal görüşünü yansıtmaz, tüm görüşler yazarlarına aittir.

Tasarım / Design: PERSPEKTİF Matbaacılık Tasarım Tic.Ltd.Şti. (0 312) 3842055 - Ankara

Basım Yeri / Printed in: PERSPEKTİF Matbaacılık Tasarım Tic.Ltd.Şti. (0 312) 3842055 - Ankara

İletişim Bilgileri / Contact Information

Sosyal Güvenlik Kurumu Başkanlığı

Ziyabey Caddesi No: 6 Balgat / Ankara / TÜRKIYE

Tel / Phone: +90 3122078891 - 2078770 - Faks / Fax: +90 3122077819

Erişim/Webpage: http://www.sgk.gov.tr/wps/portal/sgk/sgd/tr - e-posta / e-mail: sgd@sgk.gov.tr 
Professor Yener ALTUNBAȘ

Bangor University - UK

Professor Paul Leonard GALLINA

Bishop’s University - CA

Professor Jacqueline S.ISMAEL

University of Calgary - CA
Professor Özay MEHMET

University of Carleton - CA

Professor Allan MOSCOVITCH

University of Carleton - CA

Professor Mark THOMPSON

University of British Columbia - CA
Asst. Prof. Sara HSU

State University of New York- USA

Asst. Prof. C. Rada Von ARNIM

University of Utah - USA

\section{ULUSAL DANIŞMA KURULU / NATIONAL ADVISORY BOARD}

Prof. Dr. Ahmet Cevat ACAR

İstanbul Üniversitesi

İşletme Fakültesi

Prof. Dr. İsmail AĞIRBAŞ

Ankara Üniversitesi

Sağlık Bilimleri Fakültesi

Prof. Dr. Levent AKIN

Ankara Üniversitesi

Hukuk Fakültesi

Prof. Dr. Yusuf ALPER

Bursa Uludağ Üniversitesi

İktisadi ve İdari Bilimler Fakültesi

Prof. Dr. Faruk ANDAÇ

Cağ Üniversitesi

Hukuk Fakültesi

Prof. Dr. Kadir ARICI

Ankara Hacı Bayram Veli Üniversitesi

Hukuk Fakültesi

Prof. Dr. Onur Ender ASLAN

Ankara Sosyal Bilimler Üniversitesi

Siyasal Bilgiler Fakültesi

Prof. Dr. Zakir AVŞAR

Ankara Hacı Bayram Veli Üniversitesi

İletișim Fakültesi

Prof. Dr. Ufuk AYDIN

İstanbul Aydın Üniversitesi

Hukuk Fakültesi

Prof. Dr. Abdurrahman AYHAN

Kıbris İlim Üniversitesi

Hukuk Fakültesi

Prof. Dr. Serpil AYTAÇ

Bursa Uludağ Üniversitesi

İktisadi ve İdari Bilimler Fakültesi

Prof. Dr. Mehmet BARCA

Ankara Sosyal Bilimler Üniversitesi

Siyasal Bilgiler Fakültesi

Prof. Dr. Süleyman BAŞTERZI

Ankara Üniversitesi

Hukuk Fakültesi

Prof. Dr. Nursen CANIKLİOĞLU

Marmara Üniversitesi

Hukuk Fakültesi

Prof. Dr. Fevzi DEMIR

Yaşar Üniversitesi

Hukuk Fakültesi
Prof. Dr. A. Murat DEMIRCİOĞLU

Yıldız Teknik Üniversitesi

Emekli Öğretim Üyesi

Prof. Dr. Ömer EKMEKÇI

İstanbul Üniversitesi

Hukuk Fakültesi

Prof. Dr. E. Murat ENGIN

Galatasaray Üniversitesi

Hukuk Fakültesi

Prof. Dr. Hediye ERGİN

Marmara Üniversitesi

İktisat Fakültesi

Prof. Dr. Şükran ERTÜRK

Dokuz Eylül Üniversitesi

Hukuk Fakültesi

Prof. Dr. Afsun Ezel ESATOĞLU

Ankara Üniversitesi

Sağlık Bilimleri Fakültesi

Prof. Dr. Ali GÜZEL

Kadir Has Üniversitesi

Hukuk Fakültesi

Prof. Dr. Alpay HEKIMLER

Tekirdağ Namık Kemal Üniversitesi

İktisadi ve İdari Bilimler Fakültesi

Prof. Dr. Oğuz KARADENIZ

Pamukkale Üniversitesi

İktisadi ve İdari Bilimler Fakültesi

Prof. Dr. Aşkın KESER

Bursa Uludağ Üniversitesi

İktisadi ve İdari Bilimler Fakültesi

Prof. Dr. Cem KILIC

TOBB Ekonomi ve Teknoloji Üniversitesi

İktisadi ve İdari Bilimler Fakültesi

Prof. Dr. Ali Riza OKUR

İstanbul Sabahattin Zaim Üniversitesi

Hukuk Fakültesi

Prof. Dr. Serdar SAYAN

TOBB Ekonomi ve Teknoloji Üniversitesi

İktisadi ve İdari Bilimler Fakültesi

Prof. Dr. Ali Nazım SÖZER

Yaşar Üniversitesi

Hukuk Fakültesi

Prof. Dr. Sarper SÜZEK

Atılım Üniversitesi

Hukuk Fakültesi
Prof. Dr. Müjdat SAKAR

Marmara Üniversitesi

İktisat Fakültesi

Prof. Dr. Savas TASKENT

İstanbul Teknik Üniversitesi

İşletme Fakültesi

Prof. Dr. Ferda YERDELEN TATOĞLU

İstanbul Üniversitesi

İktisat Fakültesi

Prof. Dr. Sabri TEKİR

İzmir Demokrasi Üniversitesi

İktisadi ve İdari Bilimler Fakültesi

Prof. Dr. Mehmet TOP

Hacettepe Üniversitesi

İktisadi ve İdari Bilimler Fakültesi

Prof. Dr. Türker TOPALHAN

Ankara Hacı Bayram Veli Üniversitesi

İktisadi ve İdari Bilimler Fakültesi

Prof. Dr. Aziz Can TUNCAY

Bahçeşehir Üniversitesi

Hukuk Fakültesi

Prof. Dr. M. Fatih USAN

Ankara Yıldırım Beyazıt Üniversitesi

Hukuk Fakültesi

Prof. Dr. Gülbiye YENIMAHALLELI

Ankara Üniversitesi

Sağlık Bilimleri Fakültesi

Doç. Dr. Gaye BAYCIK

Ankara Üniversitesi

Hukuk Fakültesi

Doc. Dr. Emel İSLAMOĞLU

Sakarya Üniversitesi

Siyasal Bilgiler Fakültesi

Doç. Dr. Saim OCAK

Marmara Üniversitesi

Hukuk Fakültesi

Doç. Dr. Ercüment ÖZKARACA

Marmara Üniversitesi

Hukuk Fakültesi

Doç. Dr. Sinem YILDIRIMALP

Sakarya Üniversitesi

Siyasal Bilgiler Fakültesi 
Prof. Dr. Levent AKIN

Ankara Üniversitesi

Hukuk Fakültesi

Prof. Dr. Yusuf ALPER

Bursa Uludağ Üniversitesi

İktisadi ve İdari Bilimler Fakültesi

Prof. Dr. Murat ATAN

Ankara Hacı Bayram Veli Üniversitesi

İktisadi ve İdari Bilimler Fakültesi

Prof. Dr. Sibel ATAN

Ankara Hacı Bayram Veli Üniversitesi

İktisadi ve İdari Bilimler Fakültesi

Prof. Dr. Şenay ÜÇDOĞRUK BİRECIKLII

Dokuz Eylül Üniversitesi

İktisadi ve İdari Bilimler Fakültesi

Prof. Dr. Nurşen CANIKLİĞGLU

Marmara Üniversitesi

Hukuk Fakültesi

Prof. Dr. Elif GÖKÇEARSLAN ÇİFTÇİ

Ankara Üniversitesi

Sağlık Bilimleri Fakültesi

Prof. Dr. Ömer EKMEKÇİ

İstanbul Üniversitesi

Hukuk Fakültesi

Prof. Dr. Zeki ERDUT

Dokuz Eylül Üniversitesi

İktisadi ve İdari Bilimler Fakültesi

Prof. Dr. Atilla GÖKÇE

Ankara Hacı Bayram Veli Üniversitesi

İktisadi ve İdari Bilimler Fakültesi

Prof. Dr. Banu UÇKAN HEKIMLER

Anadolu Üniversitesi

İktisadi ve İdari Bilimler Fakültesi

Prof. Dr. Cemal İYEM

Aydın Adnan Menderes Üniversitesi

Söke İşletme Fakültesi
Prof. Dr. İlknur KILKIS

Bursa Uludağ Üniversitesi

İktisadi ve İdari Bilimler Fakültesi

Prof. Dr. Handan KUMAŞ

Pamukkale Üniversitesi

İktisadi ve İdari Bilimler Fakültesi

Prof. Dr. Umut OMAY

İstanbul Üniversitesi

İktisat Fakültesi

Prof. Dr. Kamil ORHAN

Pamukkale Üniversitesi

İktisadi ve İdari Bilimler Fakültesi

Prof. Dr. Serap PALAZ

Bandırma Onyedi Eylül Üniversitesi

İktisadi ve İdari Bilimler Fakültesi

Prof. Dr. Faruk SAPANCALI

Dokuz Eylül Üniversitesi

İktisadi ve İdari Bilimler Fakültesi

Prof. Dr. Filiz Elmas SARAC

Ankara Hacı Bayram Veli Üniversitesi

İktisadi ve İdari Bilimler Fakültesi

Prof. Dr. Ferda YERDELEN TATOĞLU İstanbul Üniversitesi

İktisat Fakültesi

Prof. Dr. Aysen TOKOL

Bursa Uludağ Üniversitesi

İktisadi ve İdari Bilimler Fakültesi

Prof. Dr. Suat UĞUR

Çanakkale Onsekiz Mart Üniversitesi

Biga İktisadi ve İdari Bilimler Fakültesi

Prof. Dr. Handan YOLSAL

İstanbul Üniversitesi

İktisat Fakültesi

Doç. Dr. Erdem CAM

Ankara Üniversitesi

Siyasal Bilgiler Fakültesi
Doç. Dr. Hamdi EMEÇ

Dokuz Eylül Üniversitesi

İktisadi ve İdari Bilimler Fakültesi

Doç. Dr. Furkan EMIRMAHMUTOĞLU Ankara Hacı Bayram Veli Üniversitesi İktisadi ve İdari Bilimler Fakültesi

Doç. Dr. Aycan HEPSAĞ

İstanbul Üniversitesi

İktisat Fakültesi

Doç. Dr. Recep KAPAR

Muğla Sitkı Koçman Üniversitesi

İktisadi ve İdari Bilimler Fakültesi

Doç. Dr. Serdar KURT

Çanakkale Onsekiz Mart Üniversitesi

Biga İktisadi ve İdari Bilimler Fakültesi

Doç. Dr. Banu METİN

Ankara Hacı Bayram Veli Üniversitesi

İktisadi ve İdari Bilimler Fakültesi

Doç. Dr. Nagihan DURUSOY ÖZTEPE Pamukkale Üniversitesi

İktisadi ve İdari Bilimler Fakültesi

Doç. Dr. Ramazan ŞAHIN

Gazi Üniversitesi

Mühendislik Fakültesi

Doç. Dr. Özgür TOPKAYA

Çanakkale Onsekiz Mart Üniversitesi Biga İktisadi ve İdari Bilimler Fakültesi

Doç. Dr. Özlem YORULMAZ

İstanbul Üniversitesi

İktisat Fakültesi

Dr. Öğr. Üyesi Ömer DORU

Mardin Artuklu Üniversitesi

İktisadi ve İdari Bilimler Fakültesi

Dr. Öğr. Üyesi Özlem GÖKTAŞ

İstanbul Üniversitesi

İktisat Fakültesi

Dr. Cihan Serhat KART

Ankara Üniversitesi

Ayaş Meslek Yüksekokulu 


\section{SAYI DEĞERLENDİRME ISTATISSTIKLERİ}

EVALUATION STATISTICS FOR THIS ISSUE

Toplam gelen makale başvurusu

Yayına kabul edilen makale sayısı

Hakem süreci devam eden makale sayısı

Red edilen makale sayıs

Ön inceleme aşamasında red edilen makale sayısı

Makale kabul oranı
Number of received manuscript

39

Number of accepted manuscript

Under consideration

Rejected after evaluation

Rejected before evaluation

2

Accepted manuscript rate

$\% 35$ 
İnceleme Makalesi - Review Article

\section{Türkiye'de İş-Aile Yaşamına Yönelik Düzenlemelerin Uluslararası Normlar ve Refah Rejimleri Çerçevesinde Değerlendirilmesi}

\section{Evaluation of Work-Family Life Regulations in Turkey within the Framework of International Norms and Welfare Regimes}

\author{
Sera YILDIRIM DALYAN* \\ (iD) 0000-0002-2196-4314
}

Sosyal Güvenlik Dergisi / Journal of Social Security

Cilt: 10 Say1: 2 Y1l: 2020 /Volume: 10 Issue: 2 Year: 2020

Sayfa Aralığı: 371-392 / Pages: 371-392

DOI: $10.32331 /$ sgd.841165

\section{ÖZ}

XX. yüzyılın son çeyreğinden itibaren, tüm dünyayı etkisi altına alan küreselleşmeyle birlikte Neoliberal politikalar, üretim tekniklerinin değişmesi, düşük vasıf gerektiren düşük ücretli güvencesiz işlerin yaygınlaşması, hizmet sektörünün payının artması gibi gelişmeler ekonomik alanda olduğu kadar sosyal ve kültürel alanı da derinden etkilemiştir. Yaşanan gelişmelerle şekillenen yeni çalışma hayatında özellikle tek çalışanlı aile modelinin varlığını sürdürmesi mümkün olmamış, bir buçuk veya iki çalışanlı aile modeline doğru bir dönüşüm içerisine girilmiştir. Böylece istihdama dâhil olan kadınlar, toplumsal cinsiyet rollerinin getirdiğgi sorumluluklarla birlikte iş ve aile yaşamı arasında denge sağlamakta zorlanmışlardır. Öte yandan istihdamın kadınlaşması hâlihazırda çok tartışılan evlilik yaşı, doğurganlık ve nüfusun yaşlanması gibi sorunlara da neden olmuştur. Bu doğrultuda, iş ve aile yaşamı dengesi son dönemlerde dikkat çeken konu haline gelmiş, birbirinden farklı fakat birbirleriyle ilişkili iş ve aile alanlarında dengeyi sağlamaya yönelik düzenlemeler ulusal ve uluslararası normlar bağlamında şekillendirilmiştir. Bu makalede, Türkiye'de işyaşam dengesine yönelik uygulamalar uluslararası normlar ve refah rejimleri bağlamında karşılaştırılmaktadır.

Anahtar Sözcükler: İş-yaşam dengesi, uluslararası normlar, Türkiye, refah rejimleri

\section{ABSTRACT}

Since the last quarter of the 20th century, with the globalization affecting the whole world, developments such as Neoliberal policies, changing production techniques, low-wage insecure jobs requiring low quality, and the increase in the share of the service sector have affected the social and cultural area as well as in the economic field. In the new working life, which was shaped by the developments experienced, it was not possible for the singleworker family model to continue to exist, and a transformation was made towards the one-and-ahalf or two-employee family model. Thus, women involved in employment had difficulties in balancing work and family life with the responsibilities of gender roles. On the other hand, the feminization of employment has also caused problems such as the age of marriage, fertility, and population aging, which have been much debated. Accordingly, the balance of work and family life has become a striking subject in recent times, and arrangements to balance the different but interrelated business and family areas have been shaped in the context of national and international norms. In this article, applications for work-life balance in Turkey is compared in the context of international norms and welfare regimes.

Keywords: Work-life balance, international norms, Turkey, wefare regimes

Önerilen atıf șekli: Yıldırım Dalyan, S. (2020). Türkiye'de İş-Aile Yaşamına Yönelik Düzenlemelerin Uluslararası Normlar ve Refah Rejimleri Çerçevesinde Değerlendirilmesi. Sosyal Güvenlik Dergisi (Journal of Social Security). 10(2). 371-392

\footnotetext{
* Arş. Gör., İstanbul Üniversitesi, İktisat Fakültesi, Çalışma Ekonomisi ve Endüstri İlişkileri Bölümü, sera.yildirim@istanbul.edu.tr
} 


\section{GíRíş}

Günümüzün sürekli ve hızlı bir şekilde değişen çalışma hayatında en önemli aktörü insandır. Sosyal bir varlık olan insan sadece iş yaşamında değil bireysel ve aile yaşamında rollere sahiptir. Söz konusu üç farklı yaşam alanında, rollerin getirdiği sorumlulukları dengede tutmak zorundadır. Aksi takdirde hayatın akışına uyum sağlayamayarak bireysel, toplumsal ve örgütsel birçok yönden çatışma yaşaması kaçınılmaz olacaktır.

Sanayileşme ile birlikte kadının çalışma hayatına girmesi, aile içi ayrılan zamanın azalması iş-yaşam dengesi kavramını gündeme taşımaktadır. Aslında Sanayi Devrimi'nden sonra iş ve aile hayatının sınırları birbirinden ayrışmış ve II. Dünya Savaşı'ndan sonraki gelişmeler bu durumu pekiştirmiştir. Ülkelerdeki düzenlemeler ile kadın istihdam oranları arasında pozitif yönlü ilişkinin olduğu görülmektedir. Bu çerçevede kadınların istihdama dâhil olması iki yönlü tartışılmaktadır. Bir taraftan düzenlemelerin artmasıyla kadın istihdamını arttı̆̆ tartışılırken diğer taraftan kadının istihdama dâhil olması nedeniyle iş-aile yaşamını uyumlaştırıcı düzenlemelerin zorunlu hale geldiği savunulmaktadır.

Son 40-50 yılda refah devletlerinde görülmeye başlayan yaşanan gelişmeler (yeni işgücü, yeni aile tipi, yeni şirket tipleri, yeni çalışan özellikleri, iş sözleşme türlerinin ortaya çıkması) insan hayatının merkezinde olmasına rağmen bu değişimlere ayak uydurabilme mekanizmalarının zayıf kaldığı görülmektedir. Bu süreçte küreselleşme, post-fordist üretim teknikleri, bilgi ve iletişim teknolojilerindeki gelişmeler, hizmet sektörünün payının artması, güvencesiz, düşük vasıflı ve düşük ücretli işlerin yaygınlaşması önem arz etmektedir. Bu koşullarda sadece erkeğin çalışması aile geçimi için yeterli olmayıp evli, çocuklu kadınlarında istihdama dâhil olmasına ve böylece istihdamın kadınlaşmasına neden olmuştur. Ne yazık ki erkeklere göre oluşturulmuş çalışma koşulları, kadınların işgücü piyasasına girmesiyle bu koşullara uyum sağlayamaması ve iş-aile yaşamında dengelerin bozulması kaçınılmaz bir durum olmuştur. Kadınların iş ve aile alanına ait sınırları bulanıklaşmış, kadının işgücüne dâhil olması aileyi de dönüştürmeye başlamıştır.

Yaşanan gelişmelerle genel yapının iki çalışanlı aile modelinde yoğunlaşması, çalışma ile aile hayatı arasında bir denge kurulması yönünde önem arz etmeye başlamıştır. Böylece, uluslararası ve ulusal düzeyde (anayasa, yasa, yönetmelikler) iş-aile yaşam dengesine yönelik birçok düzenleme yapılmıştır. Bu çalışmanın amacı, uluslararası normlar ve refah rejimleri ile Türkiye'de iş ve aile yaşamını uyumlaştırıcı düzenlemelerin karşılaştırılmasıdır.

\section{I- İŞ-AİLE YAŞAM DENGESINE YÖNELIKK KURAMSAL ÇERÇEVE}

Geleneksel üretim ilişkisinde iş bölümü, kadın ve erkek için farklı boyutlardadır. Erkekler daha çok üretim ve kazanç sisteminde yer alırken, kadınların ağırlıklı olarak aile içi hizmetler (anne ve eş olma) de yer aldığı görülür (Lewis, 1992: 160-165). Sanayi Devrimi’yle birlikte söz konusu geleneksel yapı değişime uğramış ve kadınların da işgücü piyasasına katılması yaşamsal zorunluluk haline gelmiştir. Bu durum aile ve toplum hayatını büyük ölçüde etkilemiştir.

Tarihsel bağlamda bakıldığında, insanlar sürekli çalışmış fakat Sanayi Devrimi'nde var olan çalışma düzenin tamamen farklılaşmıştır. Sanayi Devrimi’yle birlikte iş yeri ile aile sınırlarının birbirinden ayrılması, uzun çalışma saatleri, ailenin tüm fertlerin çalışma hayatına katılmak zorunda kalması gibi nedenlerden dolayı iş ve yaşam arasındaki dengeyi kurmak ve korumak güçleşmiştir. İşgücünün demografik özelliklerinde, aile modellerinde (çift kazançlı aile), erkek veya kadın cinsiyet rollerinde ve kariyer planlamalarında yaşanan hızlı değişimler, iş yaşam dengesini sağlayabilmek için birtakım düzenleme gerekliliklerini ortaya 
çıkarmıştır Barnett, 1999: 144). Daha sonra küreselleşme süreci ve artan rekabet olgusu iş ve aile yaşam dengesini daha fazla gündeme gelmesine yol açmıştır. Kadınların verimli çalışabilmeleri için çeşitli izinler, esnek çalışma, iş yerinde çocuk bakımı gibi bazı düzenlemeleri önem kazanmıştır (Barnett, 1999: 147-148). Yaşanan gelişmelerle önemi giderek artan iş ve aile yaşam dengesine ilişkin kuramsal yaklaşımların 20. Yüzyılın başından itibaren ortaya çıkmaya başladığı görülür. Fakat öncesinde kadınlara yönelik düzenleyici uygulamalar mevcuttur.

İş ve aile yaşam dengesi kavramı, farklı disiplinler kapsamında farklı yaklaşımlarla ele alınmıştır. Öte yandan söz konusu uygulamalar için birbirinden farklı kavramlar da kullanılmaktadır. İş hukuku teorisyenleri ve uygulamacıları “Aile Dostu İş Hukuku Uygulamaları (Family Friendly Labour Law)" kavramını kullanırken, insan kaynakları yöneticileri ve Avrupa Birliği literatürü bu uygulamalara "İ̧s-Yaşam Dengesi Uygulamaları (Work-Life Balance)" adını vermektedir (Aydın, 2011: 371). Bazı kaynaklarda ise "İ̧̧ ve Aile Yaşamının Uyumlaştırılma Uygulamaları” kavramının kullanıldığı görülmektedir.

İş ve aile yaşamını uyumlaştırmaya ilişkin uygulamalar genel olarak çalışanların hem aile hem de iş yaşamındaki sorumluluklarını yerine getirebilmelerine olanak sağlayacak düzenlemelerdir. Diğer yandan, iş-yaşam dengesi bireyin iş ve aile rolleri ile eşit oranda meşgul olup, aynı eşitlikte tatmin olması olarak tanımlanmaktadır (Greenhaus vd., 2003: 510-531). Lockwood (2003) ise iş ve aile hayatının gereği olan yükümlülüklere ait sınırları belirleyerek bu sorumlulukları yönetme ikilemi olduğuna dikkat çekmektedir (Lockwood, 2003: 3). En yalın ifadeyle ücretli iş ve aile yaşamı arasında zamanın etkin paylaşımı anlamina gelmektedir.

İş, kişisel (boş zaman etkinlikleri, dinlenme, spor vb.) ve aile hayatını kapsayan özel hayatın önceliklerinin birbiri içerisinde çatışma halinden uzak olması söz konusu alanlarda denge sağlamak açısından önemlidir (Friedman vd., 2001: 14). Aksi takdirde, iş veya özel yaşamında bireyin rollerine uyum sağlayamaması çatışmayı beraberinde getirmektedir (Duxbury ve Higgins, 2001: 3). Guest'e göre iş-yaşam dengesinin iş yerinde çalışanlara, evde ise diğer aile bireylerine iş tatmini, yaşam tatmini, ruh sağlığı ve iyi olma gibi olumlu sonuçları, stres ve hastalık gibi olumsuz sonuçları bulunmaktadır (Guest, 2002: 265).

İş yaşam dengesini, demografik ve bireysel özelliklerin yanı sıra çalışma koşulları, iş ve aile içinde yüklenilen sorumlulukların durumu etkilemektedir. Temelde üç ana faktörden etkilenmektedir. Bu faktörler; kadınların işgücüne katılımının artması, değer değişimi ve çalışma süreleri ile iş yeri kapasitesinin esnek hale getirilmesidir (Hildebrandt, 2006: 251271). Özellikle kadınların iş ve aile yaşamında uyumun sağlanması önem kazanmıştır.

\section{II- İŞ-AILLE YAŞAMINI UYUMLAŞTIRMA UYGULAMALARINA OLAN GEREKSINIM}

İş ve aile yaşamı uyumlaştırma uygulamalarında amaç, çalışanların her iki alan arasında denge kurabilmesini sağlamak olup, bu dengenin oluşması sağlıklı bir toplum açısından önem oluşturmaktadır. Çünkü işgücü piyasasına dâhil olan kadınlar iş ve aile yaşamı arasında denge kuramadıkları takdirde doğum yapmakta isteksiz davranmakta veya tek çocukla yetinmektedir. Bu durum gelecekte sosyal sigortaların finansmanını da zora sokacaktır (Schmidt, 2006: 452). Dolayısıyla ekonomik ve sosyal açıdan toplumu olumsuz etkileyecektir.

AB 2020 İstihdam Stratejisi'nde belirtildiği üzere, AB nüfusu yaşlanmaktadır ve iş-yaşam dengesini sağlayacak mevzuat ve önlemler yoluyla nüfus artışı teşvik edilmelidir. Fakat doğumlar teşvik edilirken kadın istihdamının da artırılması gerekmektedir. 
Tablo 1. Ülkelere ve Yıllara Göre Kadın İstihdam Oranı; İlk Çocuğun Doğumunda Kadınların Ortalama Yaşı, Kadın Başına Düşen Çocuk Sayısı

\begin{tabular}{|c|c|c|c|c|c|c|c|}
\hline \multirow[b]{2}{*}{ Ülkeler } & \multicolumn{3}{|c|}{$\begin{array}{c}\text { Kadın İstihdam Oranı, } \\
20+64 \text { Yaş }\end{array}$} & \multicolumn{2}{|c|}{$\begin{array}{l}\text { İlk Çocuğun Doğumunda } \\
\text { Kadınların Ortalama Yaşı }\end{array}$} & \multicolumn{2}{|c|}{$\begin{array}{c}\text { Kadın Başına Düşen } \\
\text { Çocuk Sayısı } \\
\end{array}$} \\
\hline & 2000 & 2010 & 2017 & 2005 & 2016 & 2010 & 2016 \\
\hline AB (28 ülke) & - & 62,1 & 66,5 & - & 29 & 1,62 & 1,6 \\
\hline Belçika & 56 & 61,6 & 63,6 & 27,6 & 28,8 & 1,86 & 1,68 \\
\hline Bulgaristan & 50,7 & 60,8 & 67,3 & 24,6 & 26 & 1,57 & 1,54 \\
\hline Çekya & 61,9 & 60,9 & 70,5 & 26,6 & 28,2 & 1,51 & 1,63 \\
\hline Danimarka & 72,9 & 73 & 73,7 & 28,4 & 29,3 & 1,87 & 1,79 \\
\hline Almanya & 60,8 & 69,7 & 75,2 & - & 29,4 & 1,39 & 1,6 \\
\hline Estonya & 62,8 & 65,9 & 75,1 & 25,1 & 27,5 & 1,72 & 1,6 \\
\hline İrlanda & 59,2 & 61,1 & 67 & - & 30,1 & 2,05 & 1,81 \\
\hline Yunanistan & 45,5 & 51,8 & 48 & 28,6 & 30,3 & 1,48 & 1,38 \\
\hline İspanya & 44,5 & 56,3 & 59,6 & 29,4 & 30,8 & 1,37 & 1,34 \\
\hline Fransa & - & - & 66,7 & 28,5 & 28,5 & 2,03 & 1,92 \\
\hline Hirvatistan & - & 56,4 & 58,3 & 26,4 & 28,5 & 1,55 & 1,42 \\
\hline İtalya & 42,2 & 49,5 & 52,5 & - & 31 & 1,46 & 1,34 \\
\hline Kibris & 59,1 & 68,8 & 66,2 & 27,5 & 29,6 & 1,44 & 1,37 \\
\hline Letonya & 59,3 & 64,5 & 72,7 & 25 & 26,8 & 1,36 & 1,74 \\
\hline Litvanya & 63,9 & 65 & 75,5 & 24,8 & 27,3 & 1,5 & 1,69 \\
\hline Lüksemburg & 53,1 & 62 & 67,5 & - & 30,5 & 1,63 & 1,41 \\
\hline Macaristan & 53,9 & 54,6 & 65,7 & 26,6 & 27,8 & 1,25 & 1,53 \\
\hline Malta & 33,2 & 41,6 & 60,6 & - & 29,1 & 1,36 & 1,37 \\
\hline Hollanda & 64,1 & 70,8 & 72,8 & 29 & 29,8 & 1,79 & 1,66 \\
\hline Avusturya & 62,3 & 68,8 & 71,4 & 27,3 & 29,2 & 1,44 & 1,53 \\
\hline Polonya & 54,2 & 57,3 & 63,6 & 25,7 & 27,2 & 1,41 & 1,39 \\
\hline Portekiz & 65,1 & 65,6 & 69,8 & 27,3 & 29,6 & 1,39 & 1,36 \\
\hline Romanya & 63 & 56,5 & 60,2 & 24,8 & 26,4 & 1,59 & 1,64 \\
\hline Slovenya & 63,6 & 66,5 & 69,7 & 27,7 & 28,8 & 1,57 & 1,58 \\
\hline Slovakya & 57,2 & 57,4 & 64,7 & 25,7 & 27 & 1,43 & 1,48 \\
\hline Finlandiya & 68,2 & 71,5 & 72,4 & 27,9 & 29 & 1,87 & 1,57 \\
\hline İsveç & 74,6 & 75 & 79,8 & 28,7 & 29,2 & 1,98 & 1,85 \\
\hline Birleşik Krallık & 66,8 & 67,9 & 73,1 & - & 28,9 & 1,92 & 1,79 \\
\hline İzlanda & - & 77,6 & 84,5 & 26,3 & 27,8 & 2,2 & 1,74 \\
\hline Norveç & 76,1 & 76,9 & 76,2 & 27,7 & 29 & 1,95 & 1,71 \\
\hline İsviçre & - & 73,2 & 77,4 & - & 30,7 & 1,52 & 1,54 \\
\hline Karadağ & - & - & 51,4 & 26 & - & 1,7 & - \\
\hline Makedonya & - & 37,5 & 43,7 & 25,2 & 26,9 & 1,56 & 1,5 \\
\hline Türkiye & - & 28 & 34,5 & - & - & 2,04 & 2,11 \\
\hline Kaynak: & $\begin{array}{l}\text { Veril } \\
\text { tttps:/ }\end{array}$ & $\begin{array}{l}\text { Yara } \\
\text { opa.e }\end{array}$ & $\begin{array}{l}\text { k Düz } \\
\text { tat/dat }\end{array}$ & $\begin{array}{l}\text { nmiştir; } \\
\text { tabase]. ( }\end{array}$ & 2 Kasım & & \\
\hline
\end{tabular}

Avrupa Birliği ülkelerindeki kadın istihdam oranı 2010 yılında \%62,1 oranındayken, 2017 yılında bütün zamanların en yükseği olan \%66,5'e yükselmiştir. Türkiye'de ise 2010 yılında kadın istihdam oranı \%28 iken, 2017 yılında bu oran \%34,5 olarak gerçekleşmiştir.

Dünyada tek çocuk sahibi olan aile sayısının artması doğum oranlarındaki düşüşü de beraberinde getirmektedir. 2013 yılında 28 AB ülkesinde ilk çocuk doğurma yaşı ortalaması 29 'dur. Söz konusu 28 ülkenin ortalama kadın başına düşen çocuk sayısı 2016 yılında 1,6 olarak gerçekleşmiştir. Türkiye'de ise 2010 yılında kadın başına düşen çocuk sayısı 2,04 iken, 2016 yılında 2,11 seviyesine yükselmiştir.

Doğurganlık oranlarındaki bu düşüşü, kadınların işgücü piyasasına dâhil olması ve çocuk isteksizliği ile açıklamak mümkün değildir. En önemli sorun her iki ebeveyn içinde geçerli olan çocuk bakımıdır. Fakat bu sorumlulukta toplumsal cinsiyetin getirdiği iş bölümünden büyük pay kadınlara düşmektedir. $\mathrm{Bu}$ doğrultuda kadınların ilk vardiyasını ücretli 
çalışmaları, ikinci vardiyasını ev işleri ve çocuk bakımıyla üçüncü bir vardiya oluşturmaktadır. Kadınlar kariyer beklentileri doğrultusunda hiç veya tek çocuk sahibi olma yoluna yönelmektedir.

\section{III- İŞ-AİLE YAŞAMINI UYUMLAŞTIRMA UYGULAMALARI}

İş ve aile yaşamı uyumlaştırma uygulamaları genel çerçevede iki grupta olan düzenlemeleri içermektedir. Bunlardan ilki iş yerine veya işverenin sağladığı imkânlara ilişkin olanlar iken, ikinci grubu aile yaşamına ilişkin düzenlemeler oluşturur. Burada aile kilit rol oynar çünkü aileye ilişkin her düzenleme iş yaşam uyumu ekseninde etkiye sahip olacaktır. Aile politikaları kendi içinde ebeveyn hakları, çocukların korunması ve gelir yönünden destekleyici olmak üzere üç grupta değerlendirmek mümkündür. Bunlar; vergi indirimleri, aile ve çocuk yardımları, doğum izni ve yardımları ve çocuk desteğinin güçlendirilmesine yönelik düzenlemeler sayılabilir. Aile politikaları içinde son grubu ise aile hizmetlerine ilişkin sunuma yönelik olan, çocuk bakım hizmetleri, devlet destekli konut ve sosyal hizmetler ve halk sağlığı hizmetleri oluşturmaktadır (Alcock vd., 2011: 227). Diğer bir ifade ile iş ve aile yaşamını uyumlaştırma politikalarının yasal yönünü iş yerinde çalışana yönelik düzenlemeler oluşturmaktadır. Bu çerçevede, doğum, babalık ve ebeveyn izinlerinin süreleri, ödenekleri ve kullanım koşullarına ilişkin yasalar, çocuk dışındaki diğer bakım yükümlülüklerine ilişkin düzenlemeler, işverenle çalışanın karşılıklı olarak düzenleyeceği güvenceli esneklik uygulamaları, kurumsal mekanizmalar ${ }^{1}$ ve nakit transferleri yer almaktadir.

Şekil 2. İş ve Aile Yaşamını Uyumlaştırıcı Uygulamalar

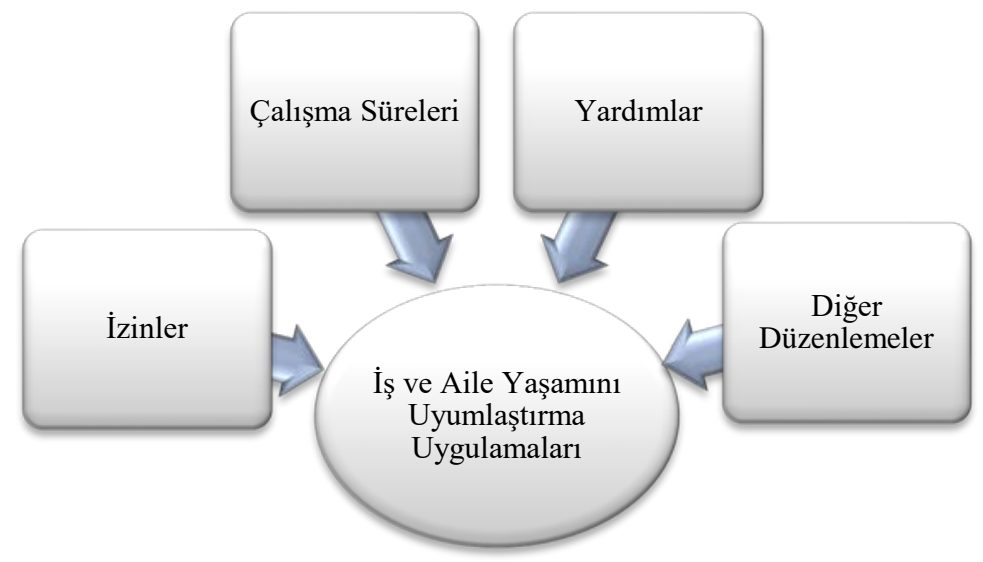

Nakit transferleri, kadının geleneksel toplumsal cinsiyet rolüne dayalı ataerkil aile yapısını destekleyici, cinsiyet ayrımcılığını pekiştirici, kadını emek piyasasından dışlayıcı ve asgari gelir düzeyinde yoksulluğu kurumsallaştırıcı niteliğinden dolayı eleştirilirken (Özaydın, 2013: 58-59), kurumsal mekanizmalar kadınların işgücü piyasasında yer almasını destekler niteliktedir.

\footnotetext{
${ }^{1}$ Okul öncesi çocuk bakımı ve eğitimine yönelik yaygın, erişilebilir ve güvenilir kurumlar ve hizmetler, okul çağındaki çocuklar için okul dışı bakım ve eğitime yönelik kurum ve hizmetler, yaşlı ve engelli bakımın kurumsal bakım ve hizmetleri.
} 
Tablo 2. İş Yaşam Dengesine Yönelik Politikalar

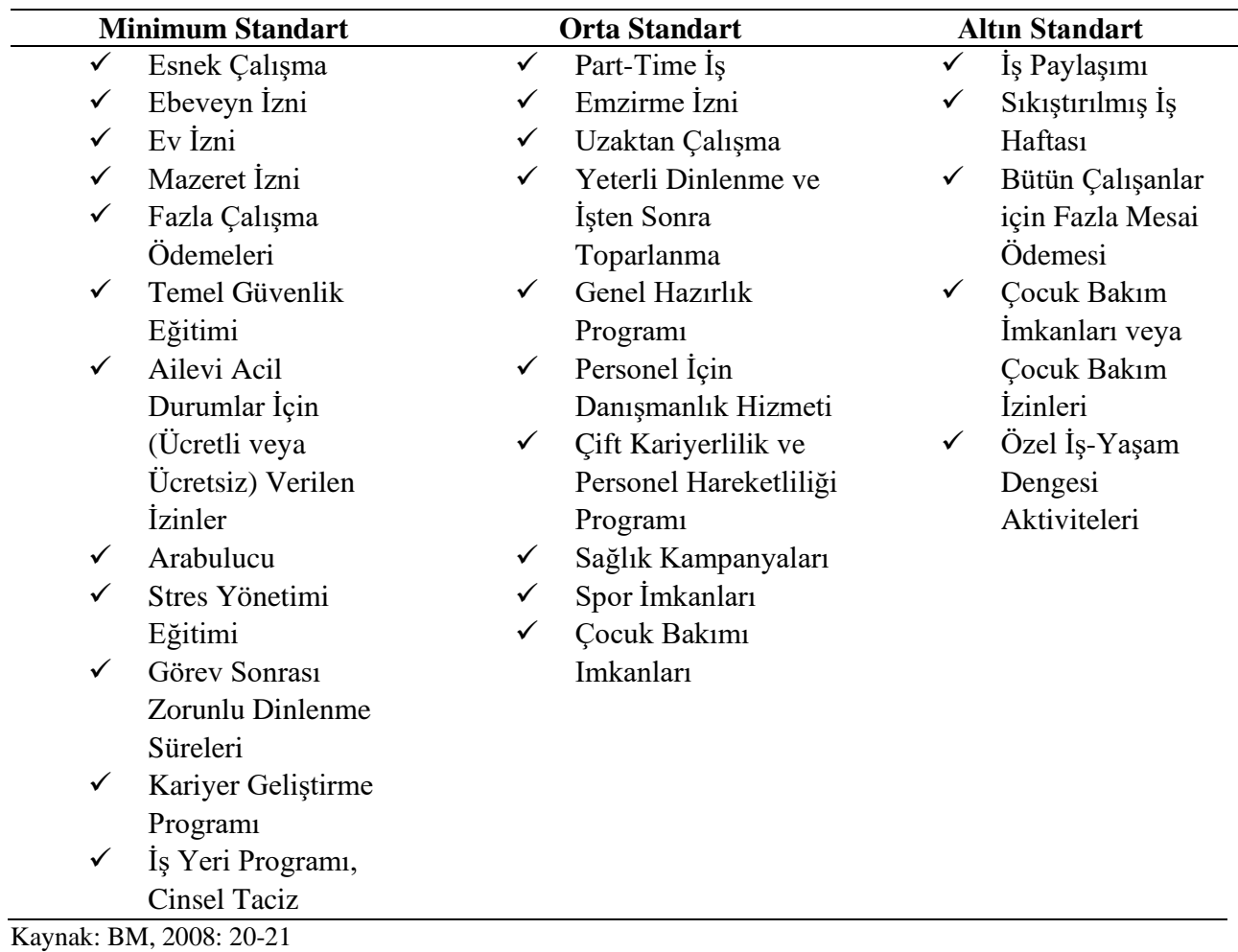

BM'nin hazırladığı rapora göre iş yaşam dengesinin sağlanması için birtakım uygulamalara yer verilmiştir. Bunlar incelendiğinde hukuki bağlamda birçok düzenlemenin olduğu görülmektedir. Tablo 2'de görüldüğü gibi iş ve aile yaşam dengesine ilişkin düzenlemeler 3 standart başlık altında ele alınmıştır. Esnek çalışma, ebeveyn izni ve mazeret izni gibi düzenlemeler minimum standart olarak belirlenirken, çocuk bakım imkânları, emzirme izni orta standart olarak sıralanmıştır. En iyi yani altın standartlar ise çocuk bakım izinleri veya çocuk bakım imkânları, sıkıştırılmış iş haftası gibi düzenlemelerdir. Bu standartlar açısından Türkiye değerlendirildiğinde, minimum standartlar ve kısmen de orta standartlar sağlayan ülkeler sinıfında yer almaktadır.

\section{IV- ULUSLARARASI HUKUK VE AB HUKUKUNDA İŞ-AİLE YAŞAMI}

İş ve aile yaşamına ilişkin düzenlemeler, sadece ülkelerin ulusal hukuk sisteminde yer almayarak, uluslararası hukuk ve $\mathrm{AB}$ hukuku çerçevesinde de düzenlenmiştir. $\mathrm{Bu}$ yasal düzenlemeleri, izinler ve çalışma sürelerine göre iki alt başlık altında inceleyebiliriz.

\section{A- İzinlere Yönelik Düzenlemeler}

Doğum, çocuk bakım ve hasta yaşlı engelli bakımı izinleri gibi uygulamalardan oluşmaktadır. İş ve aile yaşam uyumu açısından önemli izin olan doğuma bağlı izinleri de analık, babalık ve emzirme izni olarak sıralamak mümkündür. 


\section{i) Analık İzni}

Kadın çalışanlarda anneliğin korunması 1919 yılından bu yana Uluslararası Çalışma Örgütünün (ILO) temel bir meselesi olmuştur. Günümüze kadar ILO üyesi devletler anneliğin korunmasına ilișkin 1919 tarihli 3 sayılı sözleșme, 1952 tarihli 103 sayılı sözleșme ve 2000 tarihli 183 sayılı sözleşme olmak üzere, 3 sözleşme kabul etmişlerdir. Bunun dışında 95 sayılı (1952) ve 191 sayılı (2000) iki tavsiye kararları ile sözleşmelerin kapsamları genişletilmiştir.

ILO’nun 2000 tarihli 183 sayılı; Kadının Doğum ve Sonrası Çalışma Hakkındaki Sözleşme ile ücretli analık izni düzenlenmiştir. Sözleşmede yer alan hükümlere göre; doğum nedeniyle kadınlara 14 haftadan az olmayacak şekilde izin verilecek ve bilhassa doğum sonrası verilecek izin 6 haftadan az olmayacak şekilde belirlenecektir. Ayrıca kadınların ayrıldıkları iş pozisyonlara tekrar dönebilme imkânı sağlanacak, doğum nedeniyle işten hastalık yardımı yapılacak ve işten çıkarılmaları yasaklanacaktır. Son olarak günde bir veya daha fazla emzirme izini alabilecektir.

183 sayılı Sözleşme, kadına pozitif ayrımcılık sunan bir içerikte olduğu görülmektedir. Bu sözleşme Türkiye tarafından onaylanmamış olsa da mevcut mevzuatta analık halinde çalışma, doğum ve emzirme izinlerine ilişkin düzenlemeler yer almaktadır.

Analık izni süresince nakit ücret alma gerekliliği ILO’nun anneliğin korunmasıyla ilgili tüm sözleşmelerinde tanınmıştır. Nakit ücret ödemeleri yapılmadığı takdirde, kadının izin döneminde yoksulluk ve maddi sıkıntıların artmasına yol açacak ve belki de kadınların tıbben gerekli görülen süreden önce işlerine dönmelerine neden olacaktır. Diğer yandan kadınların çocuk yapmamaya sevk edecek bir durum olarak nitelendirmek de mümkündür.

19 Ekim 1992 tarihli 92/85/EEC sayılı; Gebe, Lohusa ve Emziren Kadınların İş Sağlı̆̆ı ve Güvenliği iyileştirmeyi teşvik eden önlemlerin alınmasını öngören AB yönergesi (EU, 2018) de, gebe, lohusa ve emziren kadınların iş sağlığı ve güvenliğini iyileştirmeyi teşvik edici ve gebelik ve analık nedeniyle korunmaya ilișkin düzenlemelere yer vermektedir. Üye ülkeler çalışan kadınların ulusal mevzuat ve/veya uygulamalara göre doğumdan önce ve/veya sonra en az 18 haftalık kesintisiz (Parlak, 2016: 61) analık izni alabilmelerini sağlayan önlemleri almalıdır.

4857 sayılı İş Kanunu 74. md. uyarınca, “kadın işçilerin doğumdan önce sekiz ve doğumdan sonra sekiz hafta olmak üzere toplam on altı haftalık süre içinde çalıştırılmamaları esastır. "2 Görüldüğü üzere Türkiye, ILO analık izni düzenlemesinde en az 14 haftalık standart yakalanmış olsa da, AB düzenlemelerinin (18 hafta) gerisinde olduğunu söylemek mümkündür.

\section{ii) Babalık İzni}

Babalık izni; babaya çocuğun doğumu için ve hemen sonrasında, eşiyle ve çocuklarıyla zaman geçirebilmesi için verilen ücretli izindir. BM, ILO veya AB belgelerinde babalık iznine yönelik bir düzenleme yoktur. Yani babalık iznine ilişkin uluslararası bir teamül bulunmamaktadır. 2000 tarihli AB tavsiye kararıyla (kadın ve erkeklerin iş ve aile yaşamına dengeli biçimde katılımı hk.) babalık izni hakkının tanınıp tanınmaması üye devletlere bırakılmıştı. Fakat Avrupa Parlamentosu 2010 yılında aldığ tavsiye kararıyla babalık iznini tam ücretli 2 hafta (Parlak, 2016: 61) olarak öngörmüştür. 4857 sayılı Kanun'da ek md. 2 ise "İşçiye eşinin doğum yapması halinde beş gün ücretli izin verilir" şeklinde düzenlenmiştir.

\footnotetext{
2 Detaylı bilgi için bkz. 4857 sayılı Kanun 74. md.
} 


\section{iii) Ebeveyn İzni ve Aile Bireylerine Bakım İzni}

ILO, BM ve AB belgelerinde eşlerin kendi çocukları veya evlat edindikleri çocuklar için bakım izinleri ve hasta, yaşlı ve engelli bakımı izinleri ebeveyn izni kapsamında düzenlenmiş ve bakım yükümlülüğü yalnızca kadına yüklenmemişstir (Bakırcı, 2010: 65).

Uluslararası örgütler tarafından tanımlanan bir diğer izin de ebeveynlerden herhangi birinin çocuk 2-3 yaşına gelene kadar evde kalarak kendisiyle ilgilenmesine olanak veren evde bakım-çocuk bakımı düzenlemesidir. Diğer üç izne göre daha az yaygın olan bu izin türü, genellikle ücretsiz veya çok düşük ücretle verilmektedir. Türkiye'de bunu karşılamaya en yakın düzenleme ise yarı zamanlı veya kısmi zamanlı çalışma izinleridir.

1981 tarihli 156 sayılı Aile Sorumlulukları Olan Çalışanlar Hakkında ILO Sözleşmesi, aile sorumlulukları olanların cinsiyet ayrımı olmaksızın çalışma hayatına katılımını ve iş ve aile hayatını dengelemek amacıyla ulusal politikalar izlemeleri gereğini düzenlemiştir. İş yerinde çocuk bakım ünitelerinin yer alması, çocuk bakımında baba için de izin verilmesi, aile sorumlulukları nedeniyle işten ayrılanların işe geri dönme imkânının getirilmesi gibi istihdam güvencesi sağlayan ve aileyi koruyan hükümler yer aldığı görülmektedir.

BM Pekin Platformu'nda (1995), üye devletlere, yasalar ve teşviklerle kadın ve erkekler için ebeveyn izni ve ebeveyn yardımlarını arttırma yükümlülüğü getirmiştir (Bakırcı, 2010: 66). Ayrıca "kadın ve erkekler için çalışma ve aile sorumluluklarının uyumlu olmasını yaygınlaştırmak" stratejik hedef doğrultusunda yapılacak olan eylemler belirtilmiştir (Özdamar, 2009: 716).

BUSINESSEUROPE, UEAPME, CEEP ve ETUC tarafindan karara bağlanmış, Ebeveyn İzni Hakkındaki Gözden Geçirilmiş Çerçeve Anlaşmayı yürürlüğe sokan ve 96/34/EC sayılı Direktifin İlga Edilmesine İlişkin 8 Mart 2010 tarih ve 2010/18/EU sayılı AB Yönergesi, kadın ve erkek çalışanları doğum veya evlat edinme halinde o çocuğa bakmak amacıyla en fazla sekiz yaş olmak üzere, üye devletler ve/veya sosyal ortaklar tarafindan belirlenecek bir yaşa kadar ebeveyn iznine sahip olmayı bir bireysel hak olarak tanımıştır. Avrupa Birliği'nin 2010/18/EU sayılı Ebeveyn İzni Direktifinde (Parental Leave Directive-PLD) ebeveyn izni süresi en az dört ay olmak üzere düzenlenmiştir (EU, 2018). Üye ülke mevzuatlarında bu konuya ilişkin benzer bazı düzenlemelere rastlanmaktadır.

\section{iv) Emzirme İzni}

183 sayılı analığın korunmasına ilişkin ILO Sözleşmesi’nde (2000), günde bir veya iki kere emzirme izni ya da çalışma saatlerinin ona göre azaltılması öngörülmüş ve bu süreler çalışılmış süre olarak ücretli olacaktır. 4857 md. 74 uyarınca, "Kadın işçilere bir yaşından küçük çocuklarını emzirmeleri için günde toplam bir buçuk saat süt izni verilir.” şeklinde düzenlenmiştir.

\section{B- Çalıșma Sürelerine Yönelik Düzenlemeler}

Aile Sorumlulukları Olan Kadın ve Erkek İşçilere Eşit Davranılması ve Eşit Fırsatlar Tanınmasına İlişkin 156 sayılı ILO Sözleşmesi'nde ${ }^{3}$, kadınlar ve erkekler arasında fırsat eşitliğine yönelik ulusal politikaların izlenmesi gereği düzenlenmiştir. Sözleşmenin 8 'inci maddesine göre ailevi sorumluluklar, çalışanın işten çıkarılması için geçerli sebep sayılmaz.

3156 sayılı sözleşme ILO tarafindan 23 Haziran 1981 tarihinde kabul edilmişse de Türkiye tarafından henüz onaylanmamıştır. 
Kısmi Süreli Çalışma Hakkına ilişkin 175 sayılı ILO Sözleşmesi'nde ${ }^{4}$ ise, tam gün çalışanlarla kısmi süreli çalışanların ayrımcılığa karşı eşit şekilde korunacakları, analık korunması, çalışma ilişkisini sona erdirilmesi, ücretli resmî tatiller, ücretli yıllık izin ve hastalık iznine ilişkin düzenlemelerin eşit olacağı belirtilmiştir (ILO, Part-Time Work Convention 175).

Kısmi ve tam süreli iş sözleşmesi hakkındaki 13. maddenin gerekçesinde, Avrupa Birliği Konseyi tarafından 97/81/EC sayılı Yönerge ile yürürlüğe konulan sosyal tarafların meydana getirdikleri "Kısmi Süreli Çalışma Hakkında Çerçeve Anlaşması"na uygun düzenleme yapıldığı belirtilmiştir. Bu yönergede belirtildiği üzere; "bu anlaşmanın amacl, bir yandan kısmi süreli çalışan işçilere yönelik ayrımcıliğ ortadan kaldırmak, diğer yandan kısmi zamanlı çalışmanın gelişmesine serbest irade temelinde teşvik etmek ve işverenlerle iş̧̧ilerin ihtiyaçlarını karşılayacak şekilde çalışma sürelerinin esnek bir organizasyon çerçevesinde düzenlenmesine katkıda bulunmaktır (EU, Council Directive 97/81/EC: The Framework Agreement on part-time work). İ̧ yerinde çalışan işçilerin kısmi süreliden tam süreliye ya da tam süreliden klsmi süreliye geçiş için işverence kolaylık sağlanmasına ilişkin düzenleme 97/81 sayılı Yönergenin bir gereğidir.” ifadesi yer almaktadır.

4857 sayılı Kanun'un 74. maddesinde “öngörülen izinlerin bitiminden sonra mecburi ilköğretim çă̆ının başladiğı tarihi takip eden ay başına kadar bu maddeye göre ebeveynlerden biri kısmi süreli çalışma talebinde bulunabilir." (4857 sayılı Kanun, Ek fikra: 29/1/2016-6663/21 md.).

\section{i) Refah Rejimleri Bağlamında İş-Aile}

\section{ii) Yaşamını Uyumlaştırma Uygulamaları ve Türkiye}

İş ve aile yaşamını uyumlaştırabilme amacıyla çalışma süreleri, esnek istihdam biçimleri, yapılan ödemeler, kurumsal mekanizmalar ve çeşitli projelerle düzenlenmeler yapılmıştır. $\mathrm{Bu}$ kısımda farklı refah rejimlerinde her bir refah rejimi için temsili özelliklerini taşıyan bir veya daha fazla ülke seçilerek karşılaştırma yapılmıştır.

\section{C- Esnek Çalışma Süreleri}

İş ve aile yaşam dengesi açısından esnek çalışma süreleri denildiğinde çalışma sürelerinin aileyi koruyucu şekilde düzenlenmesi ifade edilmektedir. Bu düzenlemeler, çalışanların hem iş yaşamında yer almalarını sağlarken hem de aile yapılarını korumayı amaçlamaktadır. $\mathrm{Bu}$ tür esnek çalışma şekillerinin başında kısmi süreli çalışma gelmektedir.

2016 yılında 4857 sayılı Kanun'a 6663 sayılı Kanun ile eklenen madde ve buna dayanarak çıkarılan "Analık İzni veya Ücretsiz İzin Sonrası Yapılacak Kısmı Süreli Çalışmalar Hakkında Yönetmelik'te" düzenlemeler içermektedir. Yine 4857 sayılı Kanun'un 74. maddesinde yer alan izinlerin bitiminden itibaren mecburi ilköğretim çağının başladığı tarihi takip eden aybaşına kadar ebeveynlerden biri kısmi süreli çalışma talep edebilirler ${ }^{5}$.

Doğum sonrası kısmi süreli çalışma ve yarım çalışma haklarını birbirinden ayırmak gerekir. Yarım çalışma $^{6} 4857$ sayılı Kanun'un 74/2 de yer alan süreler çerçevesinde, 4447 sayılı Kanun'daki

\footnotetext{
${ }^{4}$ ILO tarafından 24 Haziran 1994 tarihinde 175 sayılı Sözleşme Türkiye tarafından henüz onaylanmamıştır.

54857 sayılı Kanun’un 13/6. maddesine göre hangi işlerde kısmi süreli çalışma yapılabileceği, Yönetmeliğin 12. maddesinde sıralanmıştır.

${ }^{6}$ Yarım çalışma hakkını kullanacağı süreler birinci doğumda altmış gün, ikinci doğumda yüz yirmi gün ve sonraki doğumlarda ise yüz seksen gündür.
} 
koşulların sağlanması halinde, haftalık çalışma süresinin yarısı kadar çalışma imkânı tanınan işçiye aynı zamanda çalışmadığı süredeki ekonomik sıkıntıları önlemek amacıyla ücret kaybının telafisi

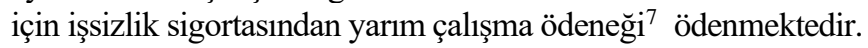

Kısmi süreli çalışma durumunda çalışanların ortaya çıkabilecek gelir kaybını telafi edecek bir mekanizma bulunmamaktadır. Öte yandan işverenlerin keyfi olarak çalışanların bu hakkını kullanmasına izin vermemesi durumunda yaptırıma yer verilmemesi ve işçiye yeterince güvence sağlanmaması bu düzenlemelerin eksik yanını göstermektedir.

Tablo 3. Cinsiyete Göre Yarı Zamanlı Çalışanların Oranı (\%).2017

\begin{tabular}{lcccc}
\hline & & Kadın & Erkek & Toplam \\
\hline Sosyal Demokrat Refah & İsveç & 34,4 & 13,1 & 23,3 \\
\cline { 2 - 5 } Devleti Rejimi & Danimarka & 35,3 & 16,2 & 25,3 \\
\cline { 2 - 5 } & Hollanda & 75,8 & 27,0 & 49,8 \\
\hline Muhafazakâr Sosyal Refah & Almanya & 46,4 & 9,7 & 26,9 \\
\cline { 2 - 5 } Devleti Rejimi & Fransa & 29,6 & 7,7 & 18,2 \\
\cline { 2 - 5 } & Belçika & 41,2 & 10,2 & 24,5 \\
\hline Liberal Refah Devleti Rejimi & Japonya & - & - & - \\
\cline { 2 - 5 } & Avusturalya & - & - & - \\
\hline Akdeniz Refah Devleti & Yunanistan & 14,1 & 6,6 & 9,7 \\
\cline { 2 - 5 } $\begin{array}{l}\text { Rejimi: Güney Avrupa } \\
\text { Ülkeleri }\end{array}$ & Ispanya & 24,1 & 7,2 & 14,9 \\
\cline { 2 - 5 } & ítalya & 32,5 & 8,3 & 18,5 \\
\cline { 2 - 5 } & Türkiye & $\mathbf{1 8 , 7}$ & $\mathbf{6 , 0}$ & $\mathbf{1 0 , 0}$ \\
\hline Eski Sosyalist Refah Devleti & Çek Cum. & 10,9 & 2,4 & 6,2 \\
\cline { 2 - 5 } Rejimi: Doğu Avrupa Ülkeleri & Polonya & 10,0 & 3,7 & 6,6
\end{tabular}

Kaynak: EUROSTAT Verilerinden Hazırlanmıştır. (Çevrimiçi) [https://ec.europa.eu/eurostat/data/database] (18 Kasım 2018)

Yarı zamanlı çalışma oranlarında görülen ülkeler arası bu farklılıkların özünde, yarı zamanlı çalışma tanımındaki farklılaşma yer almaktadır. Verilere de yansıdığı gibi ülkeler arasında yarı zamanlı çalışma oranları farklılık göstermektedir. Ancak tüm ülkelerde kadınları erkeklerden daha fazla yarı zamanlı çalışmaya yöneldiği görülmektedir. Bu durum kadınlara yüklenen toplumsal cinsiyet rollerinin getirdiği iş bölümüyle ilişkilendirilebilir. Yarı zamanlı çalışma oranına en yüksek Hollanda sahiptir. Bu oran kadınlarda \% 75,8 iken, erkeklerde \%27 olarak gerçekleşmiştir. Hollanda'da yarı zamanlı çalışmaya teşvikin yüksek olduğu görülmektedir. Türkiye'de ise kadınların yarı zamanlı çalışma oranı \%18,7, erkeklerin $\% 6$ 'dir.

Çocuk sayısı arttıkça yarı zamanlı çalışma oranları cinsiyet açısından farklılık göstermektedir. 2014 verilerine göre, Almanya'da yarı zamanlı çalışan çocuk sahibi olmayan kadınların oranı $\% 25.3$, bir çocuğu olanların \%59.4, 3 ve üzeri çocuk sahibi olan kadınların \%77.8'dir. Erkekler de ise ters orantılı olarak çocuksuz olan \%9.6, bir çocuğu olan \%5.3, iki çocuğu olan \%4.8'i yarı zamanlı çalışmaktadır. İsveç’te durum farklı değildir. Çocuk sahibi olmayan kadınlar \%24.5, bir çocuk sahibi olanlar \%32.8 ve üçten fazla çocuk sahibi olanlar 40.7 oranında yarı zamanlı çalışmaktadır. Erkekler de ise çocuksuz olan \%11.8, bir çocuğu olan \%5.8, iki çocuğu olan \%6.4'ü yarı zamanlı çalışmaktadır (EUROSTAT, 2016).

74447 sayılı Kanun Ek m.5/1, Doğum/evlat edinme sonrası ücretsiz izin ve yarım çalışma ödeneği ile ilgili detaylı bilgi için bkz. (Çevrimiçi) [http://www.mevzuat.gov.tr/MevzuatMetin/1.5.4447.pdf]. (17 Aralık 2018). 


\section{D- İzin Süreleri}

İş ve aile yaşamını dengeleyici düzenlemeler arasında izin süreleri gelmektedir. Çalışanların izin hakları ülkeden ülkeye farklılık göstermekle beraber, izin süresince yapılan ödemeler de değişmektedir. İzin süreleri doğum öncesi ve sonrası ile çocuğun yetiştirilmesi dönemlerinden oluşmaktadır. Dolayısıyla izin süreleri bağlamında analık izni, babalık izni ve ebeveyn izni olarak üç ayrı başlık konabilir. Bunların yanı sıra bakım iznine yönelik düzenlemeler de vardır.

\section{i) Analık ve Babalık İzinleri}

Analık ve babalık izinleri tüm ülkeler açısından farklılık göstermekle birlikte hemen hemen her ülkede var olan düzenlemelerdir. Bu çerçevede analık izni "Maternity Leave" doğum nedeniyle anneye verilen izinken, babalık izni "Paternity Leave" çocuğun doğumundan hemen sonra babaya verilen k1sa bir izin süresidir.

Analık İzni veya Ücretsiz İzin Sonrası Yapılacak Kısmı Süreli Çalışmalar Hakkında Yönetmelik'te analık izni "kadın işçinin doğum nedeniyle çalıştırllmadı̆̆ı süre için verilen izin” şeklinde tanımlanmıştır (Analık İzni veya Ücretsiz İzin Sonrası Yapılacak Kısmı Süreli Çalışmalar Hakkında Yönetmelik, RG. 08.11.2016-29882.). Konuyu düzenleyen 4857 sayılı Kanun'un 74. maddesinin 1. fikrasına göre, "kadın işçilerin doğumdan önce sekiz ve doğumdan sonra sekiz hafta olmak üzere toplam on altı haftalık süre için çalıştırllmamaları hükme bağlanmıştır. Şayet çoğul gebelik varsa, doğumdan önce çalıştırllmayacak sekiz haftalı süreye iki hafta daha ilave edilecektir”.

6663 sayılı Kanun'a eklenen yeni düzenlemeler içerisinde doğum öncesi veya doğum sonrası annenin ölümü halinde kullanılmayan sürelerin babaya devredilebileceği düzenlenmiştir. 6111 sayılı Kanun'da ise erken doğum halinde doğumdan önce kullanılmayan süreler doğum sonrası kullanılabilecektir. Yine evlat edinilen eşlerden birine çocuğun fiilen aileye tesliminden itibaren sekiz haftalık izin kullanma hakkı düzenlenmiştir. Söz konusu Kanun ile 4857 sayılı Kanun'un 74. maddesinde yer alan doğum izni iş sözleşmesiyle çalışan tüm işçilere uygulanabilecektir.

Tablo 4. Refah Devleti Rejimlerinde Analık ve Babalık Izinleri

\begin{tabular}{|c|c|c|c|}
\hline & & ANALIK & BABALIK \\
\hline \multirow{3}{*}{$\begin{array}{l}\text { Sosyal Demokrat Refah Devleti } \\
\text { Rejimi }\end{array}$} & Isveç & 13 Hafta & 10 Gün \\
\hline & Danimarka & 18 Hafta & 2 Hafta \\
\hline & Hollanda & 16 Hafta & 2 Gün \\
\hline \multirow{3}{*}{$\begin{array}{l}\text { Muhafazakâr } \\
\text { Devleti Rejimi }\end{array}$} & Almanya & 14 Hafta & - \\
\hline & Fransa & 16 Hafta & 11 Gün \\
\hline & Belçika & 15 Hafta & 10 Gün \\
\hline \multirow[t]{2}{*}{ Liberal Refah Devleti Rejimi } & Japonya & 14 Hafta & \\
\hline & Avusturalya & 18 Hafta & 2 Hafta \\
\hline \multirow{4}{*}{$\begin{array}{l}\text { Akdeniz Refah Devleti Rejimi: } \\
\text { Güney Avrupa Ülkeleri }\end{array}$} & Yunanistan & 119 Gün & 2 Gün \\
\hline & Ispanya & 16 Hafta & 15 Gün \\
\hline & Italya & 5 ay & 1 Gün \\
\hline & Türkiye & 16 Hafta & 5 Gün ${ }^{8}$ \\
\hline \multirow[t]{2}{*}{$\begin{array}{l}\text { Eski Sosyalist Refah Devleti } \\
\text { Rejimi: Doğu Avrupa Ülkeleri }\end{array}$} & Çek Cum. & 28 Hafta & 7 Gün \\
\hline & Polonya & 26 Hafta & 2 Hafta \\
\hline
\end{tabular}

Tablo 4'te analık izinlerini değerlendirdiğimizde 13 ile 26 hafta arasında değişen, birçok ülkede ortalama 14-16 hafta arasında seyreden izin sürelerinin olduğu görülmektedir.

${ }^{8} 657$ Sayılı Devlet Memurları Kanunu'na göre babalık izni 10 gündür. 
Türkiye'de 16 haftalık analık izin süresi hakkı vardır. Diğer yandan babalık izni Almanya'da hiç yokken, İsveç’te 10 gün, Danimarka'da 2 hafta, Polonya'da 2 hafta ve Fransa'da 11 gün olarak belirlenmiştir. Daha öncede belirttiğimiz gibi Türkiye'de 5 günlük mazeret izni altında babalara izin verilmektedir.

Genel olarak değerlendirildiğinde, Güney Avrupa ülkelerinde esnek çalışma düzenlemeleri düşük düzeydedir. İş- aile yaşamını uyumlaştırıcı uygulamalarına yönelik çabaların istenilen düzeyde olmadığı görülmektedir. Nordik ülkelerinde, kadın ve erkeğin çalıştığı çift gelirli aileler hedeflendiği için kadın istihdamını teşvik edecek iş-yaşam dengesi politikaları ön plana çıkmaktadır (Kağnıcıoğlu, 2013: 37). Dolayısıyla iş-aile yaşamını uyumlaştıran, analık ve babalık izinleri açısından en iyi düzenlemeler bu ülkelerde yer almaktadır. Aynı zamanda, Eski Sosyalist Refah Devleti Rejimlerinde de analık ve babalık izinleri oldukça iyi düzeydedir.

\section{ii) Ebeveyn İzin Düzenlemeleri}

Ebeveyn izinleri iş ve aile yaşamının uyumlaştırılması konusunda önemli düzenlemelerin başında gelmektedir. Genel olarak bilhassa aile sorumluluklarının daha çok yüklendiği kadınların iş ve aile yaşamında çatışmanın engellenmesi ve her iki yaşamda denge sağlamasına yardımcı olmaktadır. Genel olarak olumlu etkilerinden bahsedilen ebeveyn izinleri, uzun süreli ve sadece anne tarafında kullanılan bir düzenleme olursa kadınların istihdamını olumsuz etkilemektedir. Dolayısıyla bu çerçevede yapılan düzenlemelerin, en uygun düzeyde belirlenmesi ve her iki ebeveyn tarafından eşit kullanılabilmesi önem arz etmektedir. Ebeveyn izinleri daha önce değindiğimiz gibi uluslararası normlara tarafından düzenlenen fakat diğer izinlere göre daha az yaygın olan uygulamalardır. Bu düzenlemeler her ülkede farklılık göstermektedir.

Tablo 5. Ebeveyn İzin Uygulamalarl "Parental Leave"

\begin{tabular}{|c|c|c|}
\hline & Ülkeler & İzin Ücreti ve Süresi \\
\hline \multirow{3}{*}{$\begin{array}{l}\text { Sosyal Demokrat } \\
\text { Refah Devleti } \\
\text { Rejimi }\end{array}$} & Isveç & $\begin{array}{l}\text { Çocuk } 8 \text { yaşını doldurana kadar } 480 \text { günlük izin süresi. } \\
\text { Her bir ebeveyne } 60 \text { günlük ebeveyn izni. } \\
\text { İzin ücreti, kazançla orantılıdır: } 360 \text { gün için kazancın } \\
\% 80 \text { 'ni, kalan } 90 \text { gün için bu oran düşmektedir. }\end{array}$ \\
\hline & Danimarka & $\begin{array}{l}\text { Her bir ebeveyn çocuk } 9 \text { yaşını bitirene kadar } 32 \text { haftalık izin } \\
\text { alınan ücret üzerinden orantılı bir ödeme }(\% 90) \text {, } \\
\text { İzin, çocuk dokuz yaşına gelinceye kadar parça parça da } \\
\text { kullanılabilir. }\end{array}$ \\
\hline & Hollanda & $\begin{array}{l}\text { Ebeveyn izni süresi } 13 \text { haftadır ancak } 2009 \text { yılından sonra bu } \\
\text { süreyi } 26 \text { haftaya kadar uzatma hakk1 verilmiştir İzin } \\
\text { sürelerinin kullanımı esnektir. }\end{array}$ \\
\hline \multirow{3}{*}{$\begin{array}{l}\text { Muhafazakâr } \\
\text { Sosyal Refah } \\
\text { Devleti Rejimi }\end{array}$} & Almanya & $\begin{array}{l}\text { Ebeveyn izin süresi çocuk } 3 \text { yaşına gelinceye kadar } \\
\text { kullanılmaktadır. Bu iznin ilk iki y1lının çocuğun } \\
\text { doğumundan veya evlat edinilmesinden hemen sonra } \\
\text { kullanılması gerekirken, kalan süre çocuk sekiz yaşına } \\
\text { gelinceye kadar herhangi bir zamanda kullanılabilir. İzin } \\
\text { süreleri, blok halinde alınabilir. Ebeveyn, 15-30 saat arası } \\
\text { yarı zamanlı çalışabilir }\end{array}$ \\
\hline & Fransa & $\begin{array}{l}\text { Ücretsiz ebeveyn izni } 3 \text { yıldır. İzin sürelerinin kullanımı } \\
\text { esnektir, yarı zamanlı alınabilir çocuk } 3 \text { yaşını bitirene kadar } \\
\text { kullanılabilir. Ücret, ilk çocuk için } 6 \text { aylık sabit oranlıdır. }\end{array}$ \\
\hline & Belçika & $\begin{array}{l}\text { Çocuk dört yaşına gelinceye kadar her ebeveynin } 4 \text { ay } \\
\text { ebeveyn izni kullanma hakk1 vardır ve herhangi bir teste tabi } \\
\text { ebeveyn olmadan sabit bir ödeme yapılmaktadır. } \\
\text { İzin sürelerinin kullanımı esnektir ve yarı zamanlı alınabilir. }\end{array}$ \\
\hline
\end{tabular}


Tablo 5. Ebeveyn İzin Uygulamalarl "Parental Leave" (Devamı)

\begin{tabular}{|c|c|c|}
\hline $\begin{array}{l}\text { Liberal Refah } \\
\text { Devleti Rejimi }\end{array}$ & Japonya & $\begin{array}{l}\text { Çocuk } 1 \text { yaşına gelinceye kadar her ebeveynin izin kullanma } \\
\text { hakkı bulunmaktadır ve bu bireysel bir haktır. } \\
\text { Aynı zamanda her iki ebeveynin de doğum izniyle birlikte } 12 \\
\text { ay izin hakları olmasına rağmen, iznin bir kısmının } \\
\text { kullanılması halinde bu sürenin çocuk } 14 \text { aylık oluncaya } \\
\text { kadar uzatılmasına da imkân tanınmaktadır. }\end{array}$ \\
\hline & Avusturalya & 52 hafta ebeveyn izni hakkı bulunmaktadır. \\
\hline \multirow{3}{*}{$\begin{array}{l}\text { Akdeniz Refah } \\
\text { Devleti Rejimi: } \\
\text { Güney Avrupa } \\
\text { Ülkeleri }\end{array}$} & Yunanistan & $\begin{array}{l}\text { Çocuk } 6 \text { yaşını doldurana kadar her bir ebeveyn için süre 3,5 } \\
\text { aydır ve ücretsizdir. İzin sürelerinin kullanımı esnektir. }\end{array}$ \\
\hline & İspanya & $\begin{array}{l}\text { Analık izninden sonra çocuk } 3 \text { yaşına gelinceye kadar en } \\
\text { fazla bir yıl ücretsiz olarak ebeveyn izni kullanılabilir. İzin } \\
\text { sürelerinin kullanımı esnektir. }\end{array}$ \\
\hline & Italya & $\begin{array}{l}\text { Her bir ebeveyn çocuk } 8 \text { yaşına gelinceye değildir. } \\
6 \text { ay izin süresi için kazancın \%30’u kadar izin ücreti kadar } \\
\text { destek verilir. Ebeveyn izin sürelerinin kullanımı esnektir. }\end{array}$ \\
\hline $\begin{array}{l}\text { Eski Sosyalist } \\
\text { Refah Devleti } \\
\text { Rejimi: Doğu } \\
\text { Avrupa Ülkeleri }\end{array}$ & Çek Cum. & $\begin{array}{l}\text { Çocuk } 3 \text { yaşıı bitirene kadar } 156 \text { haftalık izin alınabilir. İzin } \\
\text { ücreti, 2-4 yaş arası çocuk için çeşitli seçeneklerde ödenir. } \\
\text { Ön İzin sürelerinin kullanımı esnek değildir. } \\
\text { Aylık maaşın \%70'i oranında ücret ödenir. }\end{array}$ \\
\hline Avrupa Ülkeleri & Polonya & $\begin{array}{l}\text { Çocuk } 4 \text { yaşını doldurana kadar alınabilir. Süre, ailevi olarak } \\
36 \text { aylıktır. } 24 \text { ay için sabit oranlı ücret maaşın \%60'ı oranı. } \\
\text { İzin sürelerinin kullanımı esnek değildir. }\end{array}$ \\
\hline & $\begin{array}{l}\text { Parlak, } \\
: 203 .\end{array}$ & 8-73; Dulk vd., 2011: 304; Riedman vd., 2006: 67-68; Nakazato ve \\
\hline
\end{tabular}

Refah rejimi sınıflandırmaları içerisinde en çok Güney Avrupa refah modeliyle benzerlik taşıdığ1 gözlemlenen Türkiye'de kadınların aile içi işlerden tek başına sorumlu olduğu, tek kazananlı aile modelinin yanı sıra parçalı ve hiyerarşik bir refah rejimi öne çıkmaktadır (Dedeoğlu, 2012: 211-229). Dolayısıyla iş ve aile yaşamını uyumlaştırıcı mekanizmalar daha çok geliştirilmeye çalışılmalıdır. Öte yandan Türkiye'de iş ve aile yaşamını dengeleyici düzenlemeler arasında en büyük sıkıntı erken çocuk bakımı ve eğitim hizmetlerindedir. Bu alanlara ilişkin düzenlemeler kadın istihdamı için oldukça önemli mekanizmalardır. Çünkü okul öncesi eğitimin zorunlu olması, hem onların bireysel gelişmelerini olumlu etkileyecek hem de istihdama katılan kadınların iş yükünü hafifletecektir (Ecevit, 2010: 88,110-111). Öte yandan, bakım hizmetlerine ilişkin kurumların ve sosyal politika uygulamalarının uluslararası perspektiften bakıldığında geliştirilmesi gerekmektedir (İlkkaracan, 2010: 17; Toksöz, 2012: 118).

İsveç'te iş ve yaşam dengesine yönelik uygulanan politikaların başarılı olduğu konusunda birçok araştırmacı hem fikirdir (Mary ve Rake, 2003; Lewis, 1993). İsveç’te ailesine verdiği destek salt maddi olarak sınırlı kalan ve ev içi sorumlulukları paylaşmayan baba modeli söz konusu değildir (Nyberg, 2010: 140). Bu ülkede, toplumsal cinsiyet eşitliği, ebeveyn izni ve kamu destekli çocuk bakımı gibi politikalar iş ve aile yaşamını uyumlaştırılmasında ve bilhassa kadınların ve annelerin işgücüne yüksek katılımında önemli rol oynamaktadır.

Fransa'da aile politikaları uzun süre anneleri ve çocukları korumayı temel amaç olarak benimsemiştir. 1960'lara dek, erkeğin evin ekmeğini kazandığı, kadının ise ev işlerinden sorumlu olduğu geleneksel aile model temel alınmış, kadınların evde kalmaları ve çocuk 
sahibi olmaları desteklenmiş ve hatta ve hatta ev kadınları için özel maaş desteği verilmiştir (Silvera, 2010: 146). Günümüzde de kadın istihdamının artırılmaya çalışılmasına karşın aile modeli, aile işlerinin kadın-erkek arasında paylaşılmadığg bir modeldir (Silvera, 2010: 173). Ücretsiz ebeveyn izni 3 yıldır. İki ebeveyn kullanabilir. Ücretli ebeveyn izini ise ilk çocuk için 6 ay, iki çocuk için 3 yıla dek kullanılabilir. 2004 yılından beri aylık sabit bir ödeme yapılır. (2009 Yılı için 552 Euro Aylık) (Silvera, 2010: 153). Ebeveyn izninden faydalananlar içindeki kadın oranı bakıldığında \%98'dir. Fransa'da iş ve aile hayatını dengeleyici politikaların geçmişi 19. yy'den bu yana uygulanan aile politikalarına dayanmaktadır. $\mathrm{Bu}$ ülkede anaokulu sisteminin 2-5 yaş aralığındaki tüm çocukları kapsaması örnek gösterilen ülke haline getirmiştir.

Genel bağlamda, Fransa uygulamalarıyla kendi içinde bir tutarsızlığa sahiptir. Bir yandan yoksul kesime mensup çocuklu aileleri vergiden muaf tutan bir siteminin mevcut iken, diğer yandan gelir durumundan bağımsız ve kadınların emek piyasasının dışında bırakarak, ekonomik açıdan bağımlı hale getiren CLCA adı verilen ebeveyn izin ödemeleri yapılmaktadır. Öte yandan yüksek eğitimli ve nitelikli kadınlar, pahalı çocuk bakım hizmetlerinden (çocuk bakıcılar, kreşler) faydalanabilmekte ve kariyerlerine devam etmektedir. Daha az eğitimli ve niteliksiz olan kadınlar kısmi süreli çalışma, düşük ücret ve çocuk bakım hizmetlerinden mahrumiyet dayatılmaktadır. Dolayısıyla tek seçenekleri gönülsüzde olsa ebeveyn izni almaktır (Silvera, 2010: 174).

Hollanda, 1980'lerde hâlâ evin ekmeğini erkeğin getirdiği bir aile modelindeyken günümüzde kadınların kısmi zamanlı çalışması etrafında gelişmiş çift çalışandan ziyade 1,5 çalışanlı kadının ikincil işgücü olduğu aile modeli söz konusudur (Plantenga, 2010: 194). Erkeğin tam, kadının kısmi zamanlı çalıştığı bu model ile ilk çocuk sonrası iş bırakan kadınların oranı 1980'lerde \%58 iken 2005'te \%11'e düşmüştür (Plantenga, 2010: 178-182).

İskandinav ülkelerinde yüksek destek sisteminin olduğunu söylemek mümkündür. Bu çerçevede, esnek çalışma zamanları, cömert ebeveyn izin ödemeleri, çocuk bakım hizmetleri ve ailelere doğrudan gelir transferleri gibi destekler sunulmaktadır. Bu sistemin altında yatan temel amacın, çocuk eğitimi, ebeveyn özerkliği ve cinsiyet eşitliği hedeflerinin gerçekleştirme olduğunu söylemek mümkündür. Anglo sakson (Liberal) politikalar modelinde ise, sistemin temel aracı yarı zamanlı çalışma olup, aileye yönelik sosyal yardımları ihtiyaç tespitine bağlı olarak yoksulluğu önlemek amacı gütmektedir (Thévenon, 2011: 76,182).

\section{E- Yardımlar}

Çalışanların analık döneminde işverenin ücret ödeme yükümlülüğü bulunmamaktadır. Fakat 5510 sayılı Kanun kapsamında analık halinde uğranılan gelir kaybını telafi etmek amacıyla sadece kadın çalışana geçici iş göremezlik ödeneği ödenmektedir. Bu ödenek doğumdan önce ve sonra sekizer (toplamda 16 hafta, çoğul gebelikte 20 hafta) haftalık süreyi kapsamaktadır. Ödenek tutarı; kadın sigortalının günlük kazancının yatarak tedavilerde yarısı, ayakta tedavilerde ise üçte ikisidir (5510 sayılı Kanun, m.18/6). 657 sayılı Kanun'a tabi kadınlar için bu ödeme yapılmamaktadır. Ayrıca kadın sigortalıya 5510 sayılı Kanun'a göre özel sektörde çalışması halinde emzirme ödeneği, kamu kurumunda çalışması halinde doğum yardımı ödenmektedir (Sözer, 2015: 237). 
2015 yılından itibaren ise Aile, Çalışma ve Sosyal Hizmetler Bakanlığınca tüm vatandaşlara doğum yardımı yapılması kapsamında doğum yardımı yönetmeliği çıkartılmıştır. Türk vatandaşlara canlı doğan ilk çocuk için $300 \mathrm{TL}$, ikinci ve sonraki çocuklar için sırasıyla 400 TL ve 600 TL bir defaya özgü doğum yardımı olarak verilmektedir. Özel sektör çalışanları 5510 sayılı Kanun kapsamındaki emzirme ödeneğinden ve 6637 sayılı Kanun kapsamındaki doğum yardımından birlikte yararlanabilmektedir. Fakat kamuda çalışan işçiler için yönetmelikle sınırlama yapılmıştır.

Almanya'da "çocuk parası" (Kindergeld) adı altında yardım yapılmaktadır. Çocuk parası, çocuğun Almanya'da yaşıyor veya daimi ikameti bulunuyorsa, vatandaşlığına bakılmaksızın 18 yaşını dolduruncaya kadar tüm çocuklar için çocuk parası ödenmektedir (Familienkasse, 2013: 8). Birinci ve ikinci çocuk için ödenen çocuk parası miktarı Ocak 2010 itibariyle 184 Euro, üçüncü çocuk için 190 Euro ve dördüncü ile sonraki her bir çocuk için 215 Euro ödenmektedir. Öte yandan "ebeveyn parası" (Elterngeld) adı altında gelir ile orantılı 300 Euro ile 1800 Euro arasında değişen ödeme mevcuttur. Çalışmayan kişiler için ödenen ebeveyn parası asgari 300 Euro’dur (BMFSFJ, 2013a: 12-13).

Doğurganlık oranının 1.3'lere indiği İspanya'da ise doğum yardımı olarak 2 bin 500 Euro verilmektedir. İngilizler ise 19 yaşına kadar eğitimine devam eden çocuklar için (ilk çocuk için ailelere 84 sterlin (240 lira), diğer çocuklar için 55 sterlin (150 lira)) yardımlar yapmaktadır. Fransa'da çocuk yardımı, eğitim ve konut yardımları gibi geniş teşvikler sunmaktadır. Bu çerçevede üniversite bitinceye kadar fakir ve zengin ayrımı yapılmadan herkese tek çocuk için 320 Euro, iki çocuk için 430 Euro, 3 çocuk için de 540 Euro yardım verilmektedir. İsveç de ilk üç çocuğa kadar aylık 106 Euro, dördüncü çocuğa 190 Euro destek verilmektedir (https://dogruhaber.com.tr/haber/68966-cocuk-tesviki-icin-hangi-ulke-nekadar-ucret-veriyor/).

Sonuç olarak ülkeden ülkeye farklılık gösteren çocuk bakım yardımları nakit olarak yapıldığı gibi vergi indirimleri şeklinde de yapılabilmektedir. İskandinav ülkelerinden sadece Norveç'te özel bakım satın alınması durumunda vergi indirimi uygulanmaktadır. Muhafazakâr ülkelerin ise birçoğunda vergi indirimleri bulunmakla birlikte uygulamada sınırlıdır. ABD ve Kanada'da ise oldukça yaygındır. Almanya'da vergi indirimi, evli çiftlerde ebeveynin birinin hasta veya özürlü olması ile tek ebeveynli çalışan ailelere yöneliktir (OECD, 2016; Meyers ve Gornick, 2003: 379-412 aktaran Bütün, 2010: 64).

\section{F- Diğer Düzenlemeler}

İş ve aile yaşamına ilişkin diğer düzenlemeler ise bakım ve süt izinleri, çeşitli projeler (Büyükanne maaşı projesi vb.) ve işveren uygulamaları olarak değerlendirmek mümkündür. Bakım izni çerçevesinde aile fertlerince ve ev ortamında bakımın gerçekleştirilmesi amaçlanmaktadır. Yine kurumsal bakım hizmetleri doğrultusunda Fransa'da da üç ile altı yaş arasındaki Fransız çocukları ve iki yaşındaki çocukların büyük bir bölümü devlet anaokullarına gönderilmektedir. (Crompton ve Lyonette, 2005: 383). Norveç’te ise ücretli ebeveyn izninin ardından her ebeveyn bir yıl ücretsiz izin hakkına sahiptir. Bir ile iki yaş arası çocuğu olan ebeveynler nakit para alma hakları bulunmaktadır (Brandth ve Kvande, 2016: 260). 
Tablo 6. Kurumsal Bakım Hizmetine Dâhil Olan Çocukların Oranı (ECEC ${ }^{9}$, 0-2 yaş, \%)

\begin{tabular}{|c|c|c|c|}
\hline Yll & 2005 & 2010 & 2016 \\
\hline \multicolumn{4}{|l|}{ Ülke } \\
\hline Türkiye & .. & .. & 0,3 \\
\hline Çek Cumhuriyeti & .. & .. & 6,8 \\
\hline Yunanistan & 14 & 11,3 & 11,5 \\
\hline Polonya & 2,8 & 3,8 & 12,2 \\
\hline Kıbris & 27,1 & 30,4 & 28 \\
\hline Finlandiya & 24,6 & 26,6 & 30,5 \\
\hline Birleşik Krallık & 37 & 40,1 & 31,5 \\
\hline İspanya & 14,9 & 26,3 & 34,8 \\
\hline İtalya & 27,3 & 23,3 & 35,5 \\
\hline Portekiz & 20,5 & 27,1 & 36,3 \\
\hline Almanya & 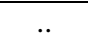 & 26,8 & 37,3 \\
\hline Slovenya & 24,8 & 34 & 38,7 \\
\hline Avustralya &.. & 38 & 39 \\
\hline İsveç & ... & 46,5 & 46,5 \\
\hline Lüksemburg & 34,8 & 45,8 & 53,1 \\
\hline Kore &.. & 38,2 & 53,4 \\
\hline Norveç & 32,7 & 52,6 & 55,3 \\
\hline Hollanda &.. &.. & 55,9 \\
\hline Fransa & 43,9 & 47,9 & 56,7 \\
\hline İzlanda & 52,6 & 54,8 & 59,7 \\
\hline Belçika &.. &.. & 59,8 \\
\hline Danimarka & .. & .. & 61,8 \\
\hline Japonya & 16,2 & 18,9 & .. \\
\hline ABD &.. & 25,8 &.. \\
\hline
\end{tabular}

İlk bölümde bahsettiğimiz kadın istihdamındaki yükseliş zorunlu olarak çocukların profesyonel bakım oranlarını yükseltmektedir. OECD'nin verileri incelendiğinde annelerin istihdamına bağlı olarak 0-2 yaşındaki bebeklerin kurumsal bakım oranları en yükseği Danimarka'da \%61,8 iken, en düşüğü \%0,3 ile Türkiye'de gerçekleşmektedir. Bu veriler Türkiye açısından değerlendirme yapabilmek için yetersiz kalmaktadır. Bu oranlar Almanya, İspanya gibi bazı ülkelerde 2005'ten 2016 yılına kadar iki katından fazla artırdığı görülmektedir. Hollanda'da \%55,9, Fransa'da \%56,7, İsveç’te \%46,5, İspanya'da \%34,8, Çin'de \%19,8, Polonya'da \%12,2 ve Çekya'da \%6,8 oranında aile dışında toplu bakım merkezlerinde çocuk bakımı gerçekleştirilmektedir.

Türkiye'nin OECD ülkelerinin aile dışı bakım oranlarının gerisinde olduğunu söylemek mümkündür. $\mathrm{Bu}$ yüzden kadınların işgücüne katılımının arttırılabilmesi için kreşlerin yaygınlaştırılması istenmektedir. Bu çerçevede "kreş haktır platformu" kurulmuştur. Öte yandan ulusal ölçekte hedeflerin belirlendiği 2014-2018 onuncu kalkınma planında çocuk bakım hizmetlerinin yaygınlaştırılması "öncelikli dönüşüm programları" içinde yer almaktadır (Büyükcoşkun, 2017: 94). Öte yandan, bakımları evin dışına çıkarılan çocukların (de-familisation) olumsuz etkileneceği ve uzun vadede olumsuz sonuçlara yol açacağı tartışılmaktadır.

Süt izni ise, emzirme izni 4857 sayılı Kanun'un 74. maddesinin 7. fikrasında düzenlenmiştir. $\mathrm{Bu}$ izin, emziren annelere çocukları bir yaşına gelene kadar günlük olarak verilmektedir. Özel

\footnotetext{
${ }^{9}$ Formal Early Childhood Education and Care

${ }^{10}$ OECD Aile İstatistikleri, (Çevrimiçi) [https://stats.oecd.org/]. (01 Aralık 2018) 
sektörde bir yaşa kadar haftada 1,5 saat, kamuda ilk altı ay 3, ikinci altı ay 1,5 saat olarak uygulanır. Kısmi zamanlı çalışmadan faydalananlar, ayrıca süt izni kullanamaz.

Öte yandan Büyükanne Maaşı: Kadın İstihdamının Desteklenmesi için Büyükanne Projesi adı altında bir proje yapılmıştır (Aile ve Çalışma, https://www.csgb.gov.tr/home/announcements/0098/). Kadın İstihdamının Desteklenmesi İçin Büyükanne Projesi'nin amacı; torununa 3 yaşına kadar bakan büyükannelere yardım yapılarak, hem çocukların büyükanneleriyle büyümelerini sağlamak ve kültürel aktarıma destek olmak hem de kadınların işgücü piyasasında yer almasını desteklemektir. Proje; Sakarya, Konya, Tekirdağ, İstanbul, Bursa, İzmir, Antalya, Ankara, Kayseri, Gaziantep illerinde on iki ay uygulanmıştır. $\mathrm{Bu}$ on iki ay boyunca 425 TL karşılıksız olarak verilmiştir. Benzer bir uygulama İspanya'da görülmektedir. İspanya "vekil anne" adı altında düzenlemelerle kadın istihdamı desteklenmiştir.

Son olarak, işveren uygulamalarında ise Gebe veya Emziren Kadınların Çalıştırılma Şartlarıyla Emzirme Odaları ve Çocuk Bakım Yurtlarına Dair Yönetmelik ${ }^{11}$ iş yerlerinde oda ve yurt açma yükümlülügüne ilişkindir. Bu Kanun doğrultusunda, 100-150 kadın çalışanın bulunduğu iş yerlerinde emzirme odasının kurulması ile 150'den fazla kadın çalışanın olduğu iş yerlerinde 6 yaşından küçük çocukların bakımı ile yönetmelikte şartları belirtilen yurtların kurulması işverenler açısından zorunlu tutulmuştur.

\section{SONUÇ}

Sanayi Devrimi ile birlikte çalışma düzenine ilişkin geleneksel yapı değişime uğramış ve kadınların da işgücü piyasasına katılması yaşamsal zorunluluk haline gelmiştir. İşgücünün demografik özelliklerinde, aile modellerinde (çift kazançlı aile), erkek veya kadın cinsiyet rollerinde ve kariyer planlamalarında yaşanan hızlı değişimler, iş yaşam dengesini sağlayabilmek için birtakım düzenleme gerekliliklerini ortaya çıkarmıştır. Küreselleşme süreci ve artan rekabet olgusu iş ve aile yaşam dengesini daha fazla gündeme getirmiştir. $\mathrm{Bu}$ durum aile ve toplum hayatını büyük ölçüde etkilemiştir. Bu doğrultuda, iş ve aile dengesine yönelik gerek ulusal gerekse uluslararası düzeyde politikalar ve yasal düzenlemeler oluşturulmuştur. Diğer bir ifade ile uluslararası normların yanı sıra her refah rejiminde farklı iş-aile yaşamını uyumlaştırıcı düzenlemeler olduğu görülmektedir. Bunlar, çalışma sürelerine, izinlere ve çeşitli yardım ve mekanizmalara yönelik düzenlemeleri içerir.

İş ve aile yaşamı uyumlaştırma uygulamaları çalışanların iş ve aile yaşamı dengesini kurabilmelerini sağlamaktadır. Bilhassa kadınların maruz kaldığı bu durum ekonomik ve sosyal yönden olumsuz sonuçlara neden olabilmektedir. Bunlardan biri de nüfusun yaşlanmasıdır. $\mathrm{Bu}$ çerçevede $\mathrm{AB}$ kapsamında iş-aile yaşam dengesini sağlayacak düzenlemeler ile önlemler alınmaktadır.

İş ve aile yaşamına ilişkin düzenlemeler, sadece ülkelerin ulusal hukuk sisteminde yer almayarak, uluslararası hukuk ve $\mathrm{AB}$ hukuku çerçevesinde de düzenlenmiştir. $\mathrm{Bu}$ yasal düzenlemeler, izinler ve çalışma sürelerine olarak değerlendirilebilir. Analık iznine ilişkin düzenlemeler hem ILO (en az 14 hafta) hem de AB (en az 18 hafta) çerçevesinde düzenlenerek standartlar belirlenmiştir. Fakat babalık iznine yönelik BM, ILO veya AB belgelerinde uluslararası bir teamül bulunmamaktadır. Uluslararası normlarda ebeveyn ve bakım izinleri düzenlenmiş ve bakım yükümlülüğü sadece kadına yüklenmemiştir. $\mathrm{AB}$ düzeyinde ebeveyn izni hem kadınlar hem de erkekler için en az 4 ay standardı belirlenirken, BM Pekin Platformu'nda ve ILO'da konuya dikkat çekilmiştir.

\footnotetext{
${ }^{11}$ Yönetmelik, RG. 16.08.2013-28737.
} 
Uluslararası normlar açısından çalışma sürelerine ilişsin düzenlemelere bakıldığında; aileyi koruyucu, ayrımcılığa karşı, kısmi süreli çalışanlar için analığın korunması, kısmi süreli çalışmanın yaygınlaştırılması gibi düzenlemeler yer almıştır. Esnek çalışma süreleri açısından tüm refah rejimlerinde kısmi süreli çalışma veya yarı zamanlı çalışma önemli düzenlemedir. Türkiye'de bu çerçevede 4857 sayılı Kanun'da düzenlemeler yapılmış hatta gerekli şartların sağlanması halinde İşsizlik Sigortası Fonundan yarım çalışma ödeneği verilmiştir. Doğum sonrası izinlerin bitiminden sonra kısmi süreli çalışmayı daha çok kadınların yöneldikleri görülmektedir. Bu durum, toplumsal cinsiyet sorumluluklarından kaynaklanmaktadır. Öte yandan, çocuk sayısı arttıkça yarı zamanlı çalışma oranları cinsiyet açısından farklılık göstermektedir.

İzinler açısından ise analık, babalık ve ebeveyn izninin yanı sıra bakım ve süt izinlerine yönelik düzenlemeler söz konusudur. Analık ve babalık izinleri tüm ülkeler açısından farklılık göstermekle birlikte hemen hemen her ülkede var olan düzenlemelerdir. Analık izinlerini incelediğimizde, Dünya'da 13 ile 26 hafta arasında değişen, birçok ülkede ortalama 14-16 hafta arasında seyreden izin süreleri mevcuttur. Babalık izni ise bazı ülkelerde hiç olmamakla beraber bazı ülkelerde 15 gün babalık izninin verildiği görülmektedir. Ebeveyn izinleri açısından ise en iyi uygulamalar sosyal demokrat refah devleti rejimindedir. Genel değerlendirme yaptığımızda, dünya' da iş-aile yaşamını uyumlaştırıcı düzenlemelerin en iyi düzeyde olduğu refah rejimleri Sosyal Demokrat Refah Devleti ve Eski Sosyalist Refah Devleti rejimleridir. Türkiye, İtalya ve Yunanistan gibi ülkeler, iş-aile yaşam dengesi politikaları açısından çok fazla gelişmemiştir. İş-aile yaşamını uyumlaştırıcı düzenlemelerden bir diğeri de yardımlardır. Bu çerçevede, 2015 yılından bu yana Türkiye'de Aile, Çalışma ve Sosyal Hizmetler Bakanlığınca tüm vatandaşlara doğum yardımı yapılmaktadır. Birçok ülkede buna benzer uygulamalar mevcuttur.

Son olarak; iş ve aile hayatının düzenlenmesi aşamasında ülkelerin farklı yollar benimsedikleri görülmektedir. Bazı ülkelerde çalışan annelerin tam zamanlı çalışmaları desteklemek amacıyla belirli sürelerde izinler ve ücret verilmekteyken, bazı ülkelerde yarı zamanlı çalışma desteklenmektedir. Bu düzenlemelerin ağırlıklı olarak kadın çalışanlara yönelik yapıldığı, erkeklere yönelik düzenlemelerin sınırlı kaldığı görülmektedir. $\mathrm{Bu}$ çerçevede, iş ve aile yaşamını uyumlaştırıcı düzenlemeler cinsiyet eşitliğini gözetecek şekilde geliştirilmelidir. Aksi takdirde kadın istihdamı üzerinde olumsuz sonuçları olacaktır. Kadın işgücü hem yarı zamanlı hem de güvencesiz çalışmasının yanı sıra aile içi sorumluluklar ile çift vardiyalı çalışmaktadır. Bu çerçevede toplumsal cinsiyet eşitsizliğini ortadan kaldırılmasına yönelik kamu politikaları, ebeveynler arasında transfer edilemez izin haklarının düzenlenmesi, kamusal bakım olanaklarının arttırılması gibi düzenlemeler uygulamaya konulmalıdır. Şüphesiz, iş-aile yaşamı dengesi kurmada sorun yaşayan sadece kadınlar değildir. Erkeklerin de iş-aile yaşamı dengesi kurmada önemli sorunları vardır. Erkelerin de iş-aile yaşamını gözeten politikalar uygulanmadıkça kadınların iş-aile yaşamı dengesini kurmaya yönelik politikalar amacına ulaşmada yeterli olmayacaktır.

ILO'nun kadınların işgücüne katılımının önündeki engelleri önlemek amacıyla oluşturduğu, aile sorumluluklarına, kısmi süreli çalışma, ev eksenli çalışma, annelik hakkının korunması ve ev işçileri için insana yakışır iş sözleşmeleri onaylanmasında fayda görülmektedir. Yine fırsat eşitliği bağlamında 4857 sayılı Kanun'un 46. maddesine babalık izni hükmü getirilerek işçiler ve memurlar arasındaki hak farkı giderilmelidir. Özellikle özel sektörde kadın çalışanların doğum sonrasında esnek çalışma taleplerine ve işe dönüşlerini garanti altına almaya yönelik hükümler 4857 sayılı Kanun'da yer almalıdır. Öte yandan, kurumsal bakım hizmetleri yaygınlaştırılmalı ve Avrupa Birliği müktesebatı ile uyum içerisinde anne ve babalara birbirlerine devredilmemek üzere ebeveyn izni yasal çerçevede yapılandırılmalıdır. 
Ayrıca, devletin özel veya kamu sektörü çalışan ayrımı yapmaksızın, çalışan annelerin çocuklarına ücretsiz kreş imkânı sağlanmalıdır.

Belirtmek gerekir ki; bu çalışmada kayıtlı olan kadın çalışanların verileri üzerinden araştırma gerçekleștirilmiștir. Gelecek çalıșmalarda ücretsiz aile çalıșanları, kendi hesabına çalışanlar, enformel ekonomide çalışanlar ve İş Kanunu kapsamı dışında bırakılmış işlerde işçi olarak çalışanların iş-aile yaşam dengesine yönelik sorunlar ele alınmalıdır.

\section{Kaynakça}

Aile, Çalışma ve Sosyal Hizmetler Bakanlığı. Büyükanne Maaşı: Kadın İstihdamının Desteklenmesi için Büyükanne Projesi. [https://www.csgb.gov.tr/home/announcements/ 0098/ ]. (Erişim: 18 Kasım 2018).

Alcock, P., May, M. ve Rowlingson, K. (2011). Sosyal Politika Kuramlar ve Uygulamalar. (Editör: Bülent Özçelik). Ankara: Siyasal Kitabevi.

Aydın, U. (2011). Aile Dostu Isş Hukuku Karşılaştırmalı Bir Inceleme. Prof. Dr. Sarper Süzek'e Armağan. (Editör: Süleyman Başterzi). İstanbul: Beta Yayınları.

Bakırcı, K. (2010). Türk Hukukunda İş ve Aile Sorumluluklarının Uzlaştırılması: Uluslararası Hukuk ve $A B$ Hukuku Çerçevesinde Bir Değerlendirme. Emek Piyasasında Toplumsal Eşitliğine Doğru: İs ve Aile Yaşamın Uzlaştırma Politikaları (Der. İpek İlkkaracan). İstanbul: Mega Bs. 59-86.

Barnett, R. C. (1999). A New Work-Life Model for the Twenty-First Century. The Annals of the American Academy of Political and Social Science. 562 (1). 143-157.

BM (2018). Work-Life Balance in the Organizations of the United Nations System Report. [http:// www . un . org / womenwatch / osagi / archive / CEB\%20 - \% 20work \% 20life \% 20balance\%2018Feb2008.pdf]. (Erişim: 25 Ekim 2018).

BMFSFJ. (2013a). Elterngeld und Elternzeit, Bundesministerium für Familie Senioren Frauen und Jugend. Druckerei Arnold Großbeeren. Berlin.

Brandth B. ve Kvande, E. (2016). "Norway”, 12th International Review of Leave Policies and Research 2016. (Editör: Alison Koslowski, Sonja Blum ve Peter Moss). 257-264.
Büyükcoşkun, S. (2017). Kadın İstihdamının Ortaya Çıkardığı Anne-Dışı Bakım Sorunu ve Türkiye'nin Kadın İstihdamı Politikasının Muhtemel Sonuçları. Sosyal Siyaset Konferansları Dergisi. 73. 85-105.

Crompton, R. ve Lyonette, C. (2005). Work-Life 'Balance' in Europe. Acta Sociologiga. 49(4). 379-393.

Daly, M. ve Rake, K. (2003). Gender and the Welfare State: Care, Work and Welfare in Europe and the USA. John Wiley and Sons. Cambridge: Polity Press.

Dedeoğlu, S. (2012). Türkiye'de Refah Devleti, Toplumsal Cinsiyet ve Kadın İstihdamı. Türkiye'de Refah Devleti ve Kadın (Der. Saniye Dedeoğlu ve A. Yavuz Elveren). İstanbul: İletişim Yayınları. 211-229.

Dulk, L. D., Peper, B., Černigoj Sadar, N., Lewis, S., Smithson, J. ve Van DoorneHuiskes, A. (2011). Work, Family and Managerial Attitudes and Practices in the European Workplace: Comparing Dutch, British and Slovenian Financial Sector Managers. Social Politics: International Studies in Gender, State and Society. 18(1). 300-329.

Duxbury, L. ve Higgins, C. (2001). Work-Life Balance in the New Millennium: Where Are We? Where Do We Need to Go. CPRN Discussion Paper. No: W12.

Ecevit, Y. (2010). İş ve Aile Yaşamının Uzlaştırılması Bağlamında Türkiye'de Erken Çocukluk Bakımı ve Eğitimi. Emek Piyasasında Toplumsal Eşittiğine Doğru: Işs ve Aile Yaşamını Uzlaştırma Politikaları (Der. İpek İlkkaracan). İstanbul: Mega Bs. 88-114. EU (1992). 92/241/EEC: Council Recommendation of 31 March 1992 on Child Care. [https://eurlex.europa.eu/eli/reco/1992/241/oj]. (Erişim:17 Kasım 2018). 
EU (1992). Council Directive 92/85/EEC of 19 October 1992 on the Introduction of Measures to Encourage Improvements in the Safety and Health at Work of Pregnant Workers and Workers Who Have Recently Given Birth or Are Breastfeeding. [https://eur-lex.europa.eu/legalcontent/EN/TXT/?uri=celex\%3A31992L0085]. (Erişim: 17 Kasım 2018).

EU (2010). Council Directive 2010/18/EU: Parental Leave. [http://eur-lex.europa.eu/legalcontent/EN/TXT/?uri=uriserv\%3Aem0031].

(Erişim: 20 Kasım 2018).

EU (1997). Council Directive 97/81/EC: The Framework Agreement on Part-Time Work. [https:// eur - lex . europa . eu / legal content/EN/TXT/?uri=celex\%3A31997L0081]. (Erişim: 18 Kasım 2018).

EUROSTAT (2018). [ https:// ec . europa . eu / eurostat/data/database ]. (Erişim: $02 \mathrm{Kasım}$ 2018).

EUROSTAT (2016). Part-Time Employment of Women in the EU Increases Drastically with Number of Children. [https:// ec . europa . eu / eurostat / documents / 2995521 / 7202372 / 3 07032016 - AP - EN .pdf/8cd72560-8188-4ef78b50-f286e288d8b8]. (Erişim: 18 Kasım 2018).

Familienkasse. (2013). Merkblatt Kindergeld. Bundeszentralamt Für Steuern.

Friedman, Stewart D., Christensen, P. ve DeGroot, J. (2001). İş ve Yaşam: Sifir Toplamlı Oyunun Sonu. Harvard Business Review: İs ve Yaşam Dengesi. İstanbul: Mess Yayınları.

Greenhaus, J. H., Collins, K. M. ve Shaw, J. D. (2003). The Relation Between Work-Family Balance and Quality of Life. Journal of Vocational Behaviour. 63(1). 510-531.

Guest, D. E. (2002). Perspevtives on the Study of Work-Life Balance. Social Sciences Information. 41(2). 255-279.

Hildebrandt, E. (2006). Balance Between Work and Life New Corporate Impositions Through Flexible Working Time or Opportunity For Time Sovereignty? European Societies. 8(2). 251-271.

ILO (2014). Maternity and Paternity at Work. [https://www.ilo.org/wcmsp5/groups/public/@d greports/@dcomm/@publ/documents/publicati on/wcms_242615.pdf]. (Erişim: 10 Kasım 2018).
ILO (2011). World Social Security Report: Providing Coverage in Times of Crisis and Beyond. 2010-2011. Geneva.

ILO (2000). Maternity Protection Convention 183. [https://www.ilo.org/dyn/normlex/en/f?p=NOR MLEXPUB:12100:0::NO::P12100_ILO_COD E:C183]. (Erişim: 04 Kasım 2018).

ILO (1981). Workers with Family Responsibilities Convention 156. [https://www.ilo.org/dyn/normlex/en/f?p=NOR MLEXPUB:12100:0::NO::P12100_ILO_COD E:C156]. (Erişimim: 18 Kasım 2018).

ILO (1994). Part-Time Work Convention 175. https://www.ilo.org/dyn/normlex/en/f?p=NOR MLEXPUB:12100:0::NO::P12100_ILO_COD E:C175]. (Erişim: 18 Kasım 2018).

İlkkaracan, İ. (2010). Giriş Bölümü. Emek Piyasasında Toplumsal Eşitliğine Doğru: $\dot{I}_{S ̧}$ ve Aile Yaşamını Uzlaştırma Politikaları (Der. İpek İlkkaracan). İstanbul: Mega Bs. 7-20.

Kağnicioğlu, D. (2013). Refah Devleti Modellerine Göre Avrupa Birliği'nde İş-Yaşam Çatışması ve İşs-Yaşam Dengesi Politikaları. Çimento Endüstrisi İşverenleri Sendikası. 27 (1). 22-39.

Koray, M. (1993). Çalışma Yaşamında Kadın Gerçekleri. Banka-Sigorta İş̧̧ileri Sendikası. Basisen: 2.

Lewis, J. E. (1993). Women and Social Policies in Europe: Work, Family and the State. Edward Elgar Pub.

Lewis, J. (1992). Gender and the Development of Welfare Regimes. Journal of European Social Policy. 2(3). 159-173.

Lockwood, N. R. (2003). Work/Life Balance: Challanges and Solutions. SHRM Research. USA. 1-12.

Meyers, M. K. ve Gornick, J. C. (2003). Public or Private Responsibility? Early Childhood Education and Care. Inequality and the Welfare State. Journal Of Comparative Family Studies. 379-412.

Nakazato, H., Nishimura, J. (2016). “Japan”. 12th International Review of Leave Policies and Research 2016. (Editör: Alison Koslowski, Sonja Blum ve Peter Moss). 203-210. 
Türkiye'de İş-Aile Yaşamına Yönelik Düzenlemelerin Uluslararası Normlar ve Refah Rejimleri Çerçevesinde Değerlendirilmesi

Nyberg, A. (2010). Çocuk Bakımına Kamu Desteği ve Ebeveyn İzni İsveç’te Ne Dereceye Kadar Etkili Oldu? Emek Piyasasinda Toplumsal Eşitliğine Doğru: İş ve Aile Yaşamını Uzlaştırma Politikaları (Der. İpek İlkkaracan). İstanbul: Mega Bs.

OECD (2018). Parental Leave Systems. [https://www.oecd.org/els/soc/PF2_1_Parental_ leave_systems.pdf]. (Erişim: 10 Kasım 2018).

OECD (2006). Starting Strong II: Early Childhood Education and Care. [http://www.oecd.org/education/school/starting strongiiearlychildhoodeducationandcare.htm]. (Erişim: 17.11.2018).

OECD (2018). OECD Aile İstatistikleri. [https:// stats . oecd . org / ] . ( Erişim : 01 Aralık 2018).

Özaydın, M. M. (2013). Cinsiyete Dayalı Refah Sınıflandırmaları Temelinde İş ve Aile Yaşamının Uyumlaştırılması Sorunu. Gazi Üniversitesi İktisadi ve İdari Bilimler Fakültesi Dergisi. 15(3). 42-72.

Özdamar, D. (2009). Türk Kadın Hukuku Mevzuatı. Ankara: Seçkin Yayınları.

Parlak, N. (2016). Avrupa Birliğinde İş-Yaşam Dengesine Yönelik Uyumlaştırma Politikaları: Ebeveyn İzni. Bilgi Sosyal Bilimler Dergisi. 1. 56-91.

Plantenga, J. (2010). Hollanda'da İş ve Aile Yaşamının Uzlaştırılması: Kısmi Zamanlı Çalışma Stratejisinin Faydaları ve Maliyetleri. Emek Piyasasinda Toplumsal Eşitliğine Doğru: İs ve Aile Yaşamını Uzlaştırma Politikaları (Der. İpek İlkkaracan). İstanbul: Mega Bs.

Ray, R. (2008). A Detailed Look at Parental Leave Policies in 21 OECD Countries. DC: Center for Economic and Policy Research. Washington.

Resmî Gazete (1999). 4447 sayılı Kanun. RG. 25.08.1999-23810.

Resmî Gazete (2016). Analık İzni veya Ücretsiz İzin Sonrası Yapılacak Kısmı Süreli Çalışmalar Hakkında Yönetmelik. RG. 08.11.2016-29882.

Resmî Gazete (2003). 4857 sayılı İş Kanunu. RG. 22.05.2003-25134.
Resmî Gazete (2011). 6111 sayılı Bazı Alacakların Yeniden Yapılandırılması ile Sosyal Sigortalar ve Genel Sağlık Sigortası Kanunu ve Diğer Bazı Kanun ve Kanun Hükmünde Kararnamelerde Değișiklik Yapılması Hakkında Kanun. RG. 25.02.2011-27857.

Resmî Gazete (1965). 657 sayılı Kanun. RG. 23.07.1965-12056.

Resmî Gazete (2013). Gebe veya Emziren Kadınların Çalıştırılma Şartlarıyla Emzirme Odaları ve Çocuk Bakım Yurtlarına Dair Yönetmelik. RG. 16.08.2013-28737.

Riedmann, Arnold, Bielenski, H., Szczurowska T. ve Wagner, A. (2006). Working Time and Work-Life Balance in EuropeanCompanies: Establisment Survey On Working Time 20042005. European Communities.

Schmidt, M. (2006). Employment, The Family and The Law: Current Problems in Germany. Comparative Labor and Policy Journal. 27 (4). 451-485.

Silvera, R. (2010). Fransa'da İş ve Aile Yaşamının Uzlaştırılması: Toplumsal Cinsiyet Eşitliği için Yeni Bir Yaklaşım Olarak Parentalizm. Emek Piyasasinda Toplumsal Eşitliğine Doğru: $\dot{I}_{\text {Şs ve Aile Yaşamın }}$ Uzlaştırma Politikaları (Der. İpek İlkkaracan). İstanbul: Mega Bs.

Sözer, A. N. (2015). Türk Sosyal Sigortalar Hukuku. İstanbul: Beta Yayınları.

Thévenon, O. Family Policies in OECD Countries: A Comparative Analysis. Population and Development Review. 37(1). 57-87.

Toksöz, G. (2012). Neoliberal Piyasa, Özel ve Kamusal Patriarka Çıkmazında Kadın Emeği. Türkiye'de Refah Devleti ve Kadın (Der. Saniye Dedeoğlu ve A. Yavuz Elveren). İstanbul: İletişim Yayınları. 103-126. 
